\title{
Carbon Sequestration in the U.S. National Parks: A Value Beyond Visitation
} Faculty Research Working Paper Series

Adam Banasiak

Harvard Kennedy School

Linda J. Bilmes

Harvard Kennedy School

John Loomis

Colorado State University

\section{February 2015 RWP15-007}

Visit the HKS Faculty Research Working Paper Series at:

https://research.hks. harvard.edu/publications/workingpapers/Index.aspx

The views expressed in the HKS Faculty Research Working Paper Series are those of the author(s) and do not necessarily reflect those of the John F. Kennedy School of Government or of Harvard University. Faculty Research Working Papers have not undergone formal review and approval. Such papers are included in this series to elicit feedback and to encourage debate on important public policy challenges. Copyright belongs to the author(s). Papers may be downloaded for personal use only. 


\section{Carbon Sequestration in the U.S. National Parks: A Value Beyond Visitation}

Faculty Research Working Paper Series

Adam Banasiak MPP'14

Linda J. Bilmes

Harvard Kennedy School

John Loomis

Colorado State University

February 2015

Linda J. Bilmes is the Daniel Patrick Moynihan Senior Lecturer in Public Policy at the Harvard Kennedy School. She serves on the Advisory Committee to the U.S. Department of Interior National Parks Service. John Loomis is a Professor of Resource Economics at Colorado State University. Adam Banasiak HKS '14 received his undergraduate degree in geosciences from Williams College. The authors gratefully acknowledge research support from the S.D. Bechtel Foundation, Turner Foundation, Summit Foundation, and National Park Foundation. 


\begin{abstract}
Carbon sequestration - the process of moderating global climate change by removing carbon dioxide from the atmosphere and storing it in long-term mineral, organic, and oceanic reservoirs - is an important ecosystem service provided by protected natural areas. One type of carbon sequestration that has received attention in recent years is vegetative carbon sequestration, which is the sequestration provided through plant growth. While a number of countries have developed estimates of their national vegetative carbon sequestration capacity, no estimate exists for the National Park Service (NPS) administered areas of the United States, $85 \%$ of which are vegetated. ${ }^{1}$ This paper addresses that knowledge gap. Using federally created, peer-reviewed work on carbon sequestration rates based on a 5-year baseline period (2001-2005) of observed data, NPS boundary data, and landcover types, the study calculates the current tonnage and economic value of vegetative carbon sequestration services on all NPS units located in the continental U.S. Average projected sequestration amounts for the period 2006-2050 are also provided based on modeled data. Using conservative assumptions, we find that at present average annual carbon sequestration on NPS lands amounts to 17.5 million metric tons of $\mathrm{CO}_{2}$, valued at $\$ 707$ million dollars using the current federal interagency working group social cost of carbon damage price of $\$ 40.45 /$ metric ton. In the future years through 2050, absent any changes in land management (such as invasive species removal or fire management) carbon sequestration is predicted to fall by $31 \%$ to an average of 12.0 million metric tons of $\mathrm{CO}_{2}$ sequestered annually, due to factors such as a warming climate and increased fire hazards. Given the benefits to society of avoiding this future loss in carbon sequestration, funding for management actions for the National Park Service may be economically justifiable in order to mitigate this decline, although further research is needed to better understand how specific NPS practices can maintain current carbon sequestration levels.
\end{abstract}

\footnotetext{
${ }^{1}$ Based on analysis of the 2011 National Land Cover Database. National Land Cover Database 2011, 2014. http://www.mrlc.gov/nlcd2011.php.
} 


\section{Introduction}

The U.S government is the nation's largest landowner, controlling some 640 million acres nationwide. The National Park Service (NPS) manages $13 \%$ of this land area, including 84 million acres distributed across all 50 states. ${ }^{2}$ The mission of the NPS has two goals: to preserve these natural and cultural resources "unimpaired", and to do so "for the enjoyment, education, and inspiration of this and future generations".

Traditionally, efforts to measure the economic value of the National Park Service units have focused exclusively on the second part of that mission: the impact to the economy generated through visitation. Two economic models developed and used by the NPS, the "Money Generation Model" (MGM) and its successor the "Visitor Spending Effects (VSE) Model", calculate the economic contribution by analyzing the number of visitors to a park, the average spending per visitor, and the multiplier effect of each dollar in the local economy. ${ }^{3}$ This type of analysis continues today with studies such as Catherine Cullinane-Thomas and coworkers in 2014. ${ }^{4}$ There have also been studies such as Christopher Neher et al. on the economic value to the visitors themselves. ${ }^{5}$ The MGM/VSE approach is the only systematic, nationwide, periodic reporting on the economic contribution generated from the NPS.

While these studies capture some of the economic effects of the NPS economy, they are not intended to estimate the significant value generated by the NPS through its stewardship mission. NPS provides a significant amount of ecosystem services, such as watershed protection, erosion control, fire management, and carbon sequestration. However, the economic value of these services has never been studied.

This paper provides a first-ever analysis of the contribution provided by NPS in an important ecosystem service related to its stewardship mission: vegetative carbon sequestration.

We chose to focus on ecosystem services for four reasons. First, ecosystem services are directly linked to the NPS mission. Effective delivery of ecosystem services is closely related to the preservation of intact environments. This supports the mission of the NPS to preserve America's natural treasures for future generations

\footnotetext{
${ }^{2}$ Other major landholders include the Fish and Wildlife Service (89 million acres), Bureau of Land Management (248 million acres) and U.S. Forest Service (193 million acres). Acreages in: Ross W. Gorte, et al. Federal Land Ownership: Overview and Data., 2012.

3 Thomas E. Fish. "Assessing economic impacts of national parks." Parks Science 26.2 (2014).

${ }^{4}$ C. Cullinane-Thomas, C. Huber, and L. Koontz. "National Park Visitor Spending Effects." Natural Resources Report NPS/NRSS/EQD/NRR—2014/824 (2013).

${ }^{5}$ Christopher Neher, John Duffield, and David Patterson. "Valuation of National Park System Visitation: The Efficient Use of Count Data Models, Meta-Analysis, and Secondary Visitor Survey Data." Environmental management 52.3 (2013): 683-98.
} 
Second, these services are relevant to a broader group of constituents because their benefits often spread far beyond park boundaries and accrue to everyone regardless of whether they visit the park units or not. While the exact value of these ecosystem services depends on many site-specific factors, they provide critical and typically underappreciated services to communities in every ecosystem. ${ }^{6}$

Third, the benefits derived from ecosystem services are vulnerable to change. Maintaining healthy ecosystems depends on the availability of funds to intervene when pests need to be controlled, disasters strike, or opportunities for restoration arise. As ecosystems degrade, some may reach tipping points where costs increase dramatically or restoration becomes impossible. Valuing ecosystem services helps to justify the resources needed now to sustain them for the future.

Finally, it is important to understand these benefits in the context of America's overall commitment to the environment. Valuing ecosystem services on federal lands is evidence of the U.S. commitment to fulfill international climate and environmental goals, such as the recent U.S.-China joint statement on climate change announcing new carbon reduction targets by both countries. $^{7}$

This estimate of NPS carbon sequestration services should be viewed as conservative. Our study excludes non-vegetative carbon sequestration that is occurring in the marine units of the NPS, such as in the coral reefs of Dry Tortugas, Virgin Islands, American Samoa, and Biscayne National Parks and through other marine pathways. ${ }^{8}$ It also excludes carbon sequestration that may be occurring through abiotic pathways, such as on barren rocks through chemical reaction with the atmosphere. Both of these have the potential to be significant carbon sinks; at present neither have been evaluated on NPS lands. Additionally, in the realm of vegetated areas, we have limited analysis to areas classified by the 2011 National Land Cover Database (NLCD) as forest, wetland, or grassland/shrubland. ${ }^{9}$ This excludes some areas, such as dune vegetation and sparsely-vegetated desert areas as well as some fields and grasslands, which may be

${ }^{6}$ A controversial 1997 paper (R. Costanza, et al. "The value of the world's ecosystem services and natural capital." Nature; Nature 387.6630 (1997): 253-60.) suggested that the value of outputs from ecosystem services should be scaled on par or greater than outputs from manmade capital, as captured by GNP estimates. A good summary of the arguments surrounding the paper is Laura Garwin's 1998 article "The worth of the earth", also in Nature (Laura Garwin. "The worth of the Earth." Nature News (1998).

${ }^{7}$ White House Office of the Press Secretary. FACT SHEET: U.S.-China Joint Announcement on Climate Change and Clean Energy Cooperation, November 11, 2014.

${ }^{8}$ Papahānaumokuākea Marine National Monument, northwest of Hawaii, protects over 89 million acres of shoals and reefs (an area greater than all NPS acreage combined) would also be excluded from these calculations. Currently, this unit is administered by the Fish and Wildlife Service, the National Oceanic and Atmospheric Administration, and the Hawai'i Department of Land and Natural Resources, not the National Park Service, which administers a majority (approximately 78 of the 110) of existing National Monuments. It is easy to see how the contribution from a large, highly productive marine area such as Papahānaumokuākea may have a large effect on the source of carbon sequestration benefits from U.S. protected areas.

9 National Land Cover Database 2011, 2014. http://www.mrlc.gov/nlcd2011.php. 
classified as agricultural or developed. In the case of maintained landscapes, such as the National Mall and many smaller historical sites and battlegrounds, we have excluded these areas completely.

Thus the total value of all carbon sequestration in the NPS is likely to be significantly higher than the $\$ 707$ million per year we have identified that is attributable to vegetative carbon offsets alone. The methodology we have introduced here may be extended to other areas of the NPS and to other protected ecosystems in future studies. ${ }^{10}$

Our study is one of the first to try to estimate the economic value of non-visitation services in the NPS, and we have focused on a specific subset of ecosystem services. The NPS also contributes economic value in a variety of fields, such as intellectual property, scientific research, education, botanical and wildlife species conservation and historical preservation. These areas merit further study, which is likely to find substantial additional reservoirs of economic value generated by NPS and its programs.

\footnotetext{
10 This methodology may be used to value carbon sequestration in federally-administered areas such as many Fish \& Wildlife and Bureau of Land Management lands, as described in Section 10, as well as important state and locally designated areas. For example, Adirondack State Park in New York State is the single largest protected land area in the continental United States.
} 


\section{Selection of Vegetative Carbon Sequestration for Valuation}

There are many types of ecosystems and within them many types of ecosystem services that may be selected as targets for possible valuation. The United Nations Environment Programme Millennium Ecosystem Assessment has grouped ecosystem services into several large bundles that are summarized in Table $1 .{ }^{11}$

Table 1: Ecosystem services organized by the United Nations Environment Programme Millennium Ecosystem Assessment (Figure adapted from the UNEP's Millennium Assessment)

\begin{tabular}{|c|c|c|}
\hline Provisioning Services & Regulating Services & Cultural Services \\
\hline $\begin{array}{c}\text { Products obtained from } \\
\text { ecosystems }\end{array}$ & $\begin{array}{c}\text { Benefits obtained from } \\
\text { regulation of ecosystem } \\
\text { processes }\end{array}$ & $\begin{array}{c}\text { Nonmaterial benefits } \\
\text { obtained from ecosystems }\end{array}$ \\
\hline $\begin{array}{l}\text { - Food } \\
\text { - Fresh water } \\
\text { - Fuelwood } \\
\text { - Fiber } \\
\text { - Biochemicals } \\
\text { - Genetic Resources/Diversity } \\
\text { Maintenance }\end{array}$ & $\begin{array}{l}\text { - Climate Regulation } \\
\text { - Disease Regulation } \\
\text { - Water Regulation } \\
\text { - Water Purification } \\
\text { - Air Purification } \\
\text { - Pollination } \\
\text { - Erosion Control }\end{array}$ & $\begin{array}{l}\text { - Spiritual and Religious } \\
\text { - Recreation and Ecotourism } \\
\text { - Aesthetic } \\
\text { - Inspirational } \\
\text { - Educational } \\
\text { - Cultural Heritage }\end{array}$ \\
\hline
\end{tabular}

Services necessary for the production of all other ecosystem services

- Soil Formation

- Nutrient Cycling

- Primary Production

The NPS has an impact across many of these categories. Of course, quantifying each ecosystem service is a separate research endeavor in and of itself. In this paper we focus on vegetative carbon sequestration related to the climate regulation service. This is not to say that vegetative carbon sequestration is the only or most important way the NPS contributes to climate regulation. However it has four key advantages for analytical purposes:

1. National Data Sets.

Nationwide, up-to-date federally prepared datasets are available for all key variables needed for quantification and valuation.

\footnotetext{
${ }^{11}$ Joseph Alcamo, Elena M. Bennett, and Ecosystem Assessment Millennium. Ecosystems and human well- being: a framework for assessment., 2003.
} 


\section{A Defensible Methodology for Calculating Value.}

A clear method capable of estimating the scale of the potential benefit was available. Calculations are further simplified by the fact that the price for a ton of carbon emissions or sequestration is constant nationally. This is true because we all share the same atmosphere, which is fairly uniformly mixed with respect to $\mathrm{CO}_{2}$. The atmosphere is the ultimate commons. No matter where a ton of carbon is added or subtracted to the atmosphere, it will eventually affect all other parts of the country irrespective of state and local boundaries. This valuation is unlike many other ecosystem services, whose costs and benefits are highly localized and dependent on local factors such as regionally dominant industries. For example, pollination services are valued more highly where agricultural areas are nearby than if they are located in remote high alpine meadows.

\section{Clear Assignment of Cost and Benefit.}

Since plants are not mobile, the NPS is the unambiguous generator of the benefit as well as responsible for the cost of maintenance and preservation of the asset. Unlike the MGM/VSE model, where proximity to a park determines the amount of economic contribution, ecosystem services broaden the cohort of NPS beneficiaries.

\section{The Service is Broadly Applicable to all NPS Units.}

Vegetative ecosystems are found in nearly all of the NPS units, especially the iconic parks, monuments, preserves, reserves, and recreation areas associated with the NPS.

This paper examines carbon sequestration on NPS-administered lands within the continental United States (CONUS), excluding approximately 54 million acres of land located in Alaska administered by the NPS. ${ }^{12}$ The reason for this omission is that data on carbon sequestration rates in Alaska have not yet been released. ${ }^{13}$

The potential impact of this omission on total net carbon sequestration across all NPS lands is unclear. As the arctic warms, peat and other accumulated vegetation may start to decompose, releasing greenhouse gases. However, increased temperatures may promote greater vegetation growth, sequestering more carbon. A further complication arises from Alaska's wide variety of ecosystem types, from temperate rainforests in the panhandle to deep tundra in the Arctic Circle. Accordingly, the impact of warming temperatures will likely vary across the NPS holdings throughout Alaska. Consequently, it is difficult to estimate the net impact of climate change across the state of Alaska at this time.

\footnotetext{
${ }^{12}$ National Park Service. Alaska Parks, 2014. http://www.nps.gov/akso/parks/Index.cfm.

13 USGS LandCarbon reports on these rates for Alaska, Hawaii, and the minor outlying islands and trust territories are scheduled to be produced within the next few years.
} 


\section{Methodology}

The method used in this study looks at each NPS unit individually and applies a formula:

\section{Net ecosystem carbon balance rate $\mathrm{x}$ area $=$ volume of carbon.}

Other approaches have been used in different national studies, which fit both the different types of data available in each country and the differing policy goals of each analysis. ${ }^{14}$ We believe the present approach is the clearest and best suited to our available datasets and our goals. An alternative calculation method is considered later in Section 5.

As a first step we estimated total present-day annual economic value of carbon sequestration based on historic data using the following calculation:

1. We determined the total forest, grassland, and wetland acreage in each NPS unit (excluding other land cover types such as ice and developed areas).

2. We then looked at the location of each park to determine its correct ecoregion. Is it in the Temperate Northeast? The cold deserts of the Western Basins? The rainforests of the Pacific Northwest?

3. We determined the relevant net ecosystem carbon balances (NECBs) rate for each ecosystem and ecoregion - how much carbon on average an acre of forest, grassland, or wetland vegetation in that ecoregion transfers from the atmosphere to terrestrial storage per calendar year.

4. We multiplied the total area of forests, wetlands, and grassland in each park by the ecoregion appropriate carbon sequestration (NECB) rate, and summed carbon sequestered in the three vegetation types to get the grand total tonnage of sequestered carbon for each NPS unit.

5. Finally, we multiplied this volume by a social damage cost per ton of carbon to compute the economic value of the storage service.

6. We repeated the process for each NPS unit. The sum of the individual park totals creates the estimated annual national economic value for the ecosystem service.

As a second step we estimated the economic value of future NPS carbon sequestration using projected average carbon sequestration rates for 2006-2050 and assumptions about future discount factors (further discussed below).

\footnotetext{
${ }^{14}$ Several countries have undertaken studies of carbon sequestration benefits in protected lands and national parks. See for example Uganda (Peter C. Howard. The economics of protected areas in Uganda: costs, benefits and policy issues (1995).), Italy (M. Marchetti, et al. "Carbon sequestration by forests in the National Parks of Italy." Plant Biosystems - An International Journal Dealing with all Aspects of Plant Biology 146.4 (2012): 1001-11.) and Canada (Suren N. Kulshreshtha, et al. Carbon sequestration in protected areas of Canada: an economic valuation. Department of Agricultural Economics, University of Saskatchewan, 2000. ).
} 


\section{Data Sources}

Our methodology requires four types of information:

1. Areas under NPS control;

2. Ecosystem types and areas within those boundaries and an identification of the ecoregion for each NPS unit;

3. The average amount of carbon sequestered for each ecosystem in each ecoregion; and

4. Damage cost per ton of carbon dioxide emitted.

The relevant sources for this data are as follows:

\section{Park Boundaries.}

The National Park Service manages lands with many different designations including National Parks, National Preserves and National Recreation Areas. National Park Service unit types and boundaries are provided in several formats (including for ArcGIS) by the NPS online at:

http://mapservices.nps.gov/arcgis/rest/services/LandResourcesDivisionTractAndBound aryService/MapServer.

\section{Ecosystem Areas.}

The 2011 National Land Cover Database (NLCD) was used to determine the area of different ecosystems within each NPS unit. This dataset is assembled by the MultiResolution Land Characteristics Consortium (MRLC; http://www.mrlc.gov/), a consortium of 13 programs in 10 different federal agencies. The consortium's goal of providing consistent national coverage of land use data in the public domain (i.e., free and readily downloadable) is ideal for this application. Data is provided in a downloadable 30-megapixel raster coded into 16 land cover classes (12 vegetation classes and 4 developed classes). The dataset is updated every 5 years.

Ecosystem types were aggregated into three classes: forests, grasslands, and wetlands. All other land cover types, such as developed and agricultural areas, were excluded from further analysis. Since the lands in question are administered by the NPS, the share of developed and agricultural lands is minimal (typically $<5 \%$ ) for larger parks. ${ }^{15}$ Areas categorized as open water, barren, or perennial snow/ice were also excluded because no national peer-reviewed dataset of carbon sequestration rates for such areas is available. However barren areas can sequester carbon through a series of reactions between minerals and acidic rainwater. Aquatic life, such as corals and foraminifera, also plays a large role in the global carbon cycle. Accordingly, the exclusion of these areas makes our estimate additionally conservative.

\footnotetext{
15 Vegetated area account for over 85\% of the total CONUS NPS acreage based on an analysis of the 2011 NLCD data.
} 


\section{Net Ecosystem Carbon Balances.}

Plants cycle carbon back and forth through the atmosphere as plants grow, die, decompose, are burned in fires and grow again. The net of all of these activities is the measure of carbon sequestration: how much carbon is added to or subtracted from the atmosphere once all vegetative processes are accounted for? This parameter, known as the "net ecosystem carbon balance" (NECB), captures the rate at which carbon is exported from the atmosphere and into storage in the living vegetative layer (biosphere) where it can rest for hundreds of years or for even longer in the pedosphere (soil layer) of the earth. The NECB is influenced by both how much carbon plants can store in a year and also by how much is released by disturbances and decay. Climatic variables such as rainfall and temperature exert the most direct influence on vegetative growth, while fire, disease damage and recreational activities (trampling, uprooting, broken branches, and so forth) also have an impact.

Regional, ecosystem and climate-specific net NECBs are available from the USGS LandCarbon National Assessment Program (http://www.usgs.gov/climate landuse/land carbon/), a congressionally-mandated assessment required in the 2007 Energy Independence and Security Act. ${ }^{16}$ The baseline USGS LandCarbon NECBs are based on historical data for the period 2001-2005 using variables such as fire frequency and severity, rainfall and temperature data as model inputs. Since plants take up carbon from the atmosphere as they grow, climatic variables such as temperature, water availability, and growing season have a large impact on the NECB of a region. Disturbances, such as wildfires, also affect the NECB because of the large amount of carbon that can be released during such events.

Since the climate of the United States is so varied, the LandCarbon National Assessment divides the CONUS into 15 regions (see Figure 1 below). These correspond to the EPA Level II ecoregion boundaries. Ecoregions are defined by both biotic and abiotic factors, such as climate, soils, and vegetation assemblages. ${ }^{17}$ For each ecoregion, LandCarbon provides the NECB for several different types of land cover, including forest, grassland/shrublands, wetlands, and agricultural use. ${ }^{18}$

\footnotetext{
${ }^{16}$ Zhiliang Zhu and Geological Survey (U.S.). A method for assessing carbon stocks, carbon sequestration, and greenhouse-gas fluxes in ecosystems of the United States under present conditions and future scenarios. Reston, Va.: U.S. Dept. of the Interior, U.S. Geological Survey, 2010.

${ }^{17}$ The ecoregion framework used here is derived from work by James Omernik for the U.S. EPA and is available online at: http://www.epa.gov/wed/pages/ecoregions.htm. The regions are the Atlantic Highlands, Central USA Plains, Cold Deserts, Mississippi Alluvial and SE Coastal Plains, Marine West Cost Forest, Mediterranean California, Mixed Wood Plains, Mixed Wood Shield, Ozark, Ouachita-Appalachian Forest, Great Plains, Southeastern USA Plains, Warm Deserts, and Western Cordillera.

${ }^{18}$ Note that there are 16 zones on the map. The zone at the tip of Florida is included in the SE coastal plain area (labeled 8.5) in the LandCarbon analysis. Additionally, the three ecoregions that make up the Great Plains (9.2, 9.3, and 9.4) are aggregated together in the LandCarbon analysis. This results in a total of 13 reporting regions for LandCarbon data.
} 
Baseline NECBs are calculated using three different models (a spreadsheet model, an erosion-deposition carbon model (EDCM), and the CENTURY model) linked to a General Ensemble Biogeochemical Modeling System (GEMS). The models are run for each year of the baseline period. ${ }^{19}$ The minimum and maximum output of each model was reported for the Western Region, while the minimum, average, and maximum outputs were reported for the Eastern Region. ${ }^{20}$ For the Great Plains ecoregion, only the average was reported. ${ }^{21}$

\section{A summary of the LandCarbon baseline NECBs used in our analysis is provided in Appendix 1.}

Figure 1: Level II Ecoregions of the CONUS. Base and future NECBs are available for each ecoregion for forest, grassland/shrubland, and wetland ecosystems in that ecoregion. (Image from LandCarbon 2010) 22

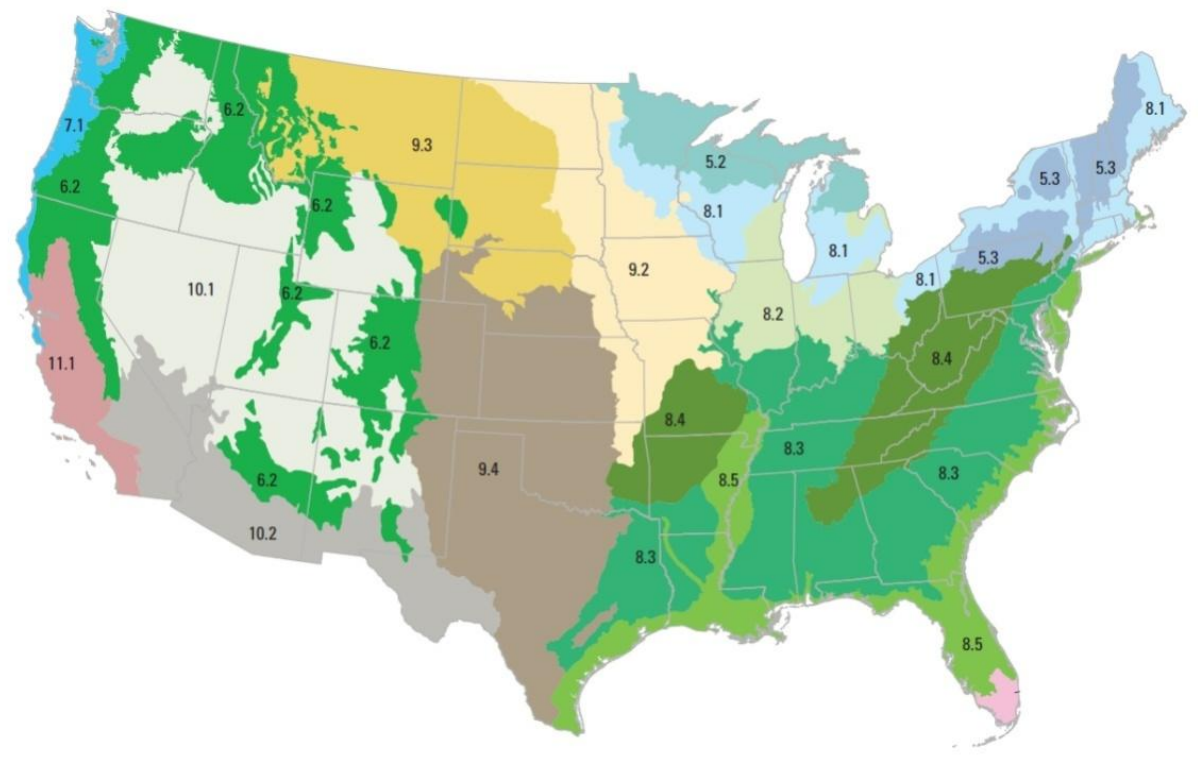

\footnotetext{
${ }^{19}$ For details on how the model was assembled, the inputs, and the number of runs see; Zhiliang Zhu and Geological Survey (U.S.). A method for assessing carbon stocks, carbon sequestration, and greenhouse-gas fluxes in ecosystems of the United States under present conditions and future scenarios. Reston, Va.: U.S. Dept. of the Interior, U.S. Geological Survey, 2010.
}

${ }^{20}$ To address this data gap for the Western Region, this paper uses the mathematical average between the reported maximum and minimum scenarios for the Western Region. We compared the Eastern Region's reported average with the mathematical average and noted that the reported average was higher than the mathematical average, suggesting this approach was conservative.

${ }^{21}$ Since there are few NPS units in this ecoregion and this data will have only minor impact on the nationwide tally, to allow us to make nationwide minimum and maximum assessments for all NPS units, this study uses the reported average NECBs for the Great Plains ecoregion as the minimum and maximum NECB as well.

22 Zhiliang Zhu and Geological Survey (U.S.). A method for assessing carbon stocks, carbon sequestration, and greenhouse-gas fluxes in ecosystems of the United States under present conditions and future scenarios. Reston, Va.: U.S. Dept. of the Interior, U.S. Geological Survey, 2010. 
LandCarbon compares its data and NECB estimates to both measured and computed NECBs from other studies in order to assess the accuracy of the model output. Where data is available intermediate products are also compared to existing measured and calculated data, for example the USDA's forest biomass estimates. ${ }^{23}$

In addition to the baseline estimates for current conditions, NECB estimates for the period 2006-2050 are also available. Since the future is uncertain, 21 GEMS model runs were performed under varying scenarios. As with the baseline calculations, the Spreadsheet, EDCM, and CENTURY models were used, this time in conjunction with three different future climate assumptions taken from the UNEP IPCC-SRES. ${ }^{24,25}$ The projected NECBs were calculated as the difference between the carbon stocks in adjacent years. The annual projected NECBs for the period 2006-2050 were then averaged for each model run. The result is the total average NECB for the entire period 2006-2050 rather than any specific year. For the Eastern US Region, the minimum, average, and maximum NECBs resulting from these 21 models are reported. For the Western region, only the minimum and maximum results are reported. For the Great Plains ecoregion, only the average is reported. ${ }^{26}$ A summary of the future NECBs is shown in Appendix 1.

\section{Damage cost per ton of carbon dioxide emitted.}

Cost data is discussed in Section 6 below.

\footnotetext{
${ }^{23}$ For example, the r-squared and other statistical variables comparing the results for areas where other studies have been conducted are available in the full USGS LandCarbon reports.

${ }^{24}$ United Nations Environment Programme Intergovernmental Panel on Climate Change Special Report on Emissions Scenarios. The UNEP homepage is available at: http://www.unep.org/.

${ }^{25}$ A detailed description of this process can be found in the LandCarbon reports, both in the Methodology paper and starting on page 111 of the Western Region report.

${ }^{26}$ See the preceding baseline section for how this paper addressed this reporting gap.
} 


\section{Alternate Data Processing Methods}

In addition to the data contained in the four released USGS LandCarbon reports, the LandCarbon team has also, through the LandCarbon website, ${ }^{27}$ released additional raw data and model outputs as well as created an interactive map/data interface. This makes it possible to limit the NECB analysis area solely to the footprint of the NPS units, without needing to use the ecoregion/ecosystem NECBs reported in the LandCarbon reports that are created using data for the entire ecoregion (i.e., with data from both inside and outside of NPS units).

We would expect that, if this alternative method using NECBs created solely from in-park data were used, aggregate $\mathrm{CO}_{2}$ storage tonnage would remain within the same range as reported here. However we have chosen to use the LandCarbon report data for two reasons. First, it significantly reduces workload burden because no additional calculations are needed, which may make the use of this method more attractive to the NPS and other government agencies with similar conservation missions (the Fish and Wildlife Service, the U.S. Forest Service, etc.).

Second, by using data from both inside and outside of the parks, drawing upon a large area, these ecosystem rates average out of some the spatial and temporal heterogeneity inherit in measuring NECBs, lowering the peaks from areas with bumper years and raising the troughs of areas under drought and other stresses to provide a better long-term average idea of what might occur in a given NPS unit. While a small area such as a park may experience a few very good or very bad years with respect to carbon sequestration (due to droughts, etc.), it is unlikely these effects will impact the entire ecoregion. Accordingly, we believe the ecoregion average estimates of NECB in the LandCarbon reports may give a better estimate of the 'average' NPS contribution than an estimate clipped to the actual park boundaries and based on a baseline of only five years (2001-2005). Clipping the boundaries in this way could result in negative carbon sequestration estimates for NPS units for the period 2001-2005. While this makes sense over the short-term, over the long-term, all vegetative environments sequester carbon, or at least remain carbon neutral.

${ }^{27}$ U.S. Geological Survey (USGS). 2014. LandCarbon Website. National Assessment of Ecosystem Carbon Sequestration and Greenhouse Gas Fluxes. http://www.usgs.gov/climate_landuse/land_carbon/. 


\section{Social Damage Cost of Carbon}

A key set of assumptions in our calculation is the social damage cost of carbon and the discount rate applied to value future carbon sequestration. For the dollar valuation, we use the 2013 update of the Executive Order 12866 Interagency Working Group estimate of the Social Cost of Carbon, which determined a price of $\$ 40.45$ per metric ton of carbon. ${ }^{28}$

The Interagency Working Group produces estimates of the SCC using a 2.5\%, 3\%, and 5\% discount rate in order to calculate the present value of future carbon damages resulting from current emissions. In this paper we use a 3\% discount rate, which aligns our study with the recent Regulatory Impact Analysis (RIA) for the EPA's Clean Power Plan-a major new piece of greenhouse gas regulation - that also uses a $3 \%$ discount rate. ${ }^{29}$ We recognize that there is wide disagreement on the proper discount rate for SCC estimates, in part because of the very long time horizons involved and because of intergenerational equity concerns. Assumptions for the most appropriate discount rate range cover a wide range. For example, Lord Nicholas Stern used 1.4\% in his 700-page landmark 2007 study of climate change, while Yale economist William Nordhaus has used an estimate of $4.3 \% .{ }^{30,31}$ Sunstein and Weisbach provide an excellent summary of the thinking behind the various approaches to the discount rate. ${ }^{32}$

From a global perspective, the U.S. estimate for the social cost of carbon is somewhat lower than other national estimates. The mean price from a review of all peer-reviewed literature is $\$ 43$ per ton. However a literature review of 103 SCC prices by Richard Tol in 2005 range from $\$ 14$ to $\$ 165$ (upper $90 \%$ confidence interval) with a mean estimate of $\$ 93$ a ton. ${ }^{33}$ Differences between models result from a wide range of factors, including differences in assumptions and models for adaptation costs, the impact of changes on the developing world, and future technological change.

\footnotetext{
${ }^{28}$ The Interagency Working Group is led by the Council of Economic Advisors and the Office of Management and Budget, in cooperation with ten other agencies (in alphabetical order): Council of Economic Advisers, Council on Environmental Quality*, Department of Agriculture, Department of Commerce, Department of Energy, Department of Transportation, Domestic Policy Council, Environmental Protection Agency, National Economic Council, Office of Management and Budget*, Office of Science and Technology Policy, Department of the Treasury. (* = chairs)

${ }^{29}$ United States Environmental Protection Agency Air, Economics Group. Regulatory impact analysis for the proposed carbon pollution guidelines for existing power plants and emission standards for modified and reconstructed power plants. U.S. Environmental Protection Agency, Office of Air Quality Planning and Standards, Health \& Environmental Impacts Division, Air Economics Group, 2014.

30 Stern, Nicholas Herbert. Stern Review: The economics of climate change. Vol. 30. London: HM treasury, 2006.

31 William Nordhaus. "A review of the Stern Review on the economics of climate change." Journal of economic literature 45.3 (2007): 686-702.

32 David Weisbach and Cass R. Sunstein. "Climate Change and Discounting the Future: A Guide for the Perplexed." Yale Law \& Policy Review 27.2 (2009): 433-57.

33 Richard Tol. "The marginal damage costs of carbon dioxide emissions: an assessment of the uncertainties." Energy Policy 33.16 (2005): 2064-74.
} 
A potential problem with the Interagency SCC discount rates is that they are assumed to be constant over time. Nordhaus suggests that for long-horizon problems, such as the SCC, a declining discount rate is more appropriate. ${ }^{34}$ Using a declining discount rate would result in a higher SCC; therefore our use of a constant 3\% may be viewed as conservative.

Outside the choice of discount rate, there are three other potential methodological issues that should be considered when applying the SCC, which may make the Interagency SCC estimate too high or too low compared to the "true" SCC. These include the global nature of the estimate, the comprehensive nature of the estimate, and poor handling of catastrophic damages.

\section{Global estimation of damages.}

The interagency SCC estimate takes account of the damage per ton of emissions caused not just in the United States but globally. This reflects the reality that climate change is a global problem given the interconnected nature of global supply chains, food, oil, capital, and other markets. This could potentially differ from the purely domestic economic cost of a ton of carbon in the United States.

\section{Comprehensiveness of the SCC.}

Some potentially important impacts of climate change are not accounted for in the interagency carbon cost modeling. The interagency approach tries to account for all damage resulting from carbon emissions, regardless of what sector they impact, by using three of the most widely used and respected Integrated Assessment Models (IAMs). ${ }^{35,36,37}$ Such models link physical changes in temperature and other climate variables to economic changes across a broad range of human health, agriculture, capital, ecosystem services, and other sectors. However the approach is still by no means comprehensive, in part because climate change researchers still lack a solid enough scientific and economic understanding of many processes to be able to include them in IAMs. IAMS (including these three) are likely to exclude environmental impacts such as ocean acidification and permafrost melt because our understanding of these complex ecological processes is still rudimentary.

As a result of excluding these processes, the SCC may be too low because it does not account for all of the cost impacts. For example, ocean acidification will impact coral reefs such as those in Biscayne National Park, National Park of American Samoa, and Dry Tortugas National Park. NPS, along with other conservation agencies and state and local governments, may respond through conservation programs for threatened corals or

\footnotetext{
34 See for a further discussion: K. Arrow, et al. "Determining Benefits and Costs for Future Generations." Science 341.6144 (2013): 349-50.

35 William Nordhaus. "Estimates of the Social Cost of Carbon: Concepts and Results from the DICE-2013R Model and Alternative Approaches." Journal of the Association of Environmental and Resource Economists 1.1 (2014): 273-312.

${ }^{36}$ David Anthoff and Richard Tol. FUND Model. wwww.fund-model.org. (2014)

${ }^{37}$ Chris Hope. The Marginal Impact of $\mathrm{CO}_{2}$ from PAGE 2002. Integrated Assessment Journal 6(1): 9-56. (2006)
} 
related marine species, research efforts to develop possible responses, or increased policing of fragile or weakened coral areas. None of these costs borne by federal, state, and local governments or by individuals associated with these activities are currently captured by the SCC.

\section{Catastrophic damage.}

The selected IAMs do not do a good job capturing the potential for catastrophic damages such as floods and fires or their associated restoration costs. For example extensive damage from Hurricane Andrew resulted in Everglades National Park being listed as a World Heritage in Danger site by the United Nations Educational, Scientific and Cultural Organization (UNESCO), the only site on the list in the United States and Canada. ${ }^{38}$ The result is an additional conservative bias in resulting SCC calculations. Compounding this bias is that catastrophes may push ecosystems past tipping points, either making restoration impossible or greatly increasing the costs.

${ }^{38}$ United Nations Educational, Scientific, and Cultural Organization (UNESCO), "World Heritage Committee inscribes Everglades National Park on List of World Heritage in Danger," July 23, 2010. 


\section{The Results: Baseline Assessment}

Using the baseline carbon sequestration rates from the period 2001-2005 and the method outlined above, we calculated the present-day annual carbon sequestration value for the NPS units in the continental United States (CONUS). We excluded a small number of NPS units due to data gaps or data quality. These are all small in size (accounting in total for less than half of one percent of total NPS CONUS land area) and thus not material in the overall calculation. ${ }^{39}$ The results of our analysis are summarized in Table 2 below; a unit-by-unit breakdown is provided in Appendix 2. A visual summary of Table 2 is also presented in Figure $2 .{ }^{40}$

The average annual sequestration is estimated to be nearly 17.5 million metric tons of carbon dioxide, providing over $\$ 700$ million dollars of ecosystem service value. The parks, preserves, reserves, recreation areas, and rivers alone sequestered $92 \%$ of the annual total, or 16.0 million metric tons of carbon dioxide, with two-thirds of the total coming from units designated as parks alone. Nearly one-fifth (18.6\%) of the total sequestration in all NPS units occurs in Everglades National Park and adjacent Big Cypress National Preserve. A listing of all the individual NPS units that contribute at least $0.5 \%$ of the total baseline carbon sequestration is provided in Appendix 2 in order to help more fully understand where the bulk of carbon sequestration services in the NPS are occurring.

There is a wide range-a more than seven-fold difference-between the maximum and the minimum estimates shown in Table 2. Unfortunately, the LandCarbon data source does not provide confidence intervals for its NECB data. This is because some of the model inputs do not have well-bounded error ranges and because the models used to generate the output are not fully integrated. Rather, LandCarbon chooses to use a selection of models to generate the greatest likely range, in their professional opinion, of potential outcomes.

\footnotetext{
${ }^{39}$ CONUS NPS units not included in this analysis due to data issues such as missing data or reorganizations of units are: River Raisin National Battlefield, Cane River Creole National Heritage Park and Heritage Area, New Orleans Jazz National Heritage Park, Paterson Great Falls National Heritage Park, Carter G. Woodson Home National Historic Site, First Ladies National Historic Site, Theodore Roosevelt Birthplace National Historic Site, Federal Hall National Memorial, General Grant National Memorial, Hamilton Grange National Memorial, Port Chicago Navel Magazine National Memorial, African Burial Ground National Monument, Cesar E. Chavez National Monument, Charles Young Buffalo Soldiers National Monument, First State National Monument, Harriet Tubman Underground Railroad National Monument, Great Egg Harbor National Scenic and Recreational River, Rio Grande Wild and Scenic River, Appalachian National Scenic Trail, Natchez Trace National Scenic Trail, Potomac Heritage National Scenic Trail. In addition, the National Capital Parks were not included. The Mcloughlin House and the Peterson House, sometimes included with other units (Fort Vancouver \& Ford's Theatre, respectively), are listed separately. Additionally, the areas now comprising Parashant National Monument are included in the estimate for Lake Mead National Recreation Area. Together, the excluded units comprise less than half of one percent of that total NPS CONUS land area.

40 With appreciation to Dan Mahr for his assistance in interpreting the ecosystem acreage data from ArcGIS.
} 
Table 2: Carbon sequestration estimates in CONUS NPS units based on 2001-2005 baseline estimates.

\begin{tabular}{|c|c|c|c|c|}
\hline \multirow[b]{3}{*}{ NPS Unit Type } & \multicolumn{4}{|c|}{ Baseline 2001-2005 Estimates } \\
\hline & \multirow{2}{*}{$\begin{array}{c}\text { Average } \\
\text { (\$mm) } \\
\text { USD } \$ 2013 \\
\$ 40.45 / \text { ton }\end{array}$} & Min & Average & Max \\
\hline & & \multicolumn{3}{|c|}{ Million Metric Tons of $\mathrm{CO}_{2}$} \\
\hline Parks & $\$ 472.35$ & 2.92 & 11.68 & 19.63 \\
\hline Preserves, Reserves & $\$ 87.91$ & 0.36 & 2.17 & 3.56 \\
\hline Recreation Areas & $\$ 45.26$ & 0.05 & 1.12 & 2.16 \\
\hline Rivers, Wild \& Scenic Rivers & $\$ 42.45$ & 0.51 & 1.05 & 1.44 \\
\hline Subtotal & $\$ 647.97$ & 3.84 & 16.02 & 26.79 \\
\hline Lakeshores, Seashores & $\$ 21.69$ & 0.23 & 0.54 & 0.73 \\
\hline Monuments & $\$ 13.74$ & -0.09 & 0.34 & 0.76 \\
\hline Parkways & $\$ 10.58$ & 0.12 & 0.26 & 0.37 \\
\hline Historical Parks & $\$ 6.71$ & 0.06 & 0.17 & 0.25 \\
\hline $\begin{array}{c}\text { Battlefields, Battlefield Sites, } \\
\text { Military Parks }\end{array}$ & $\$ 4.52$ & 0.04 & 0.11 & 0.16 \\
\hline Other NPS Designations & $\$ 1.65$ & 0.02 & 0.04 & 0.06 \\
\hline Historic Sites & $\$ 0.84$ & 0.01 & 0.02 & 0.03 \\
\hline Memorials & $\$ 0.16$ & 0 & 0 & 0 \\
\hline Grand Total & $\$ 707.86$ & 4.24 & 17.50 & 29.16 \\
\hline
\end{tabular}

\section{Comparing Carbon Benefits to the NPS Budget}

To provide a comparison to these social benefits of $\$ 707.86$ million, the NPS enacted budget in 2014 was approximately $\$ 2.5$ billion. ${ }^{41}$ Of the total, the vegetative carbon sequestration generated by NPS units and activities in the CONUS offset more than one-quarter of the funds taxpayers spent for the entire NPS system. It is important to keep in mind, however, that this is simply one ecosystem service. As mentioned above, we have excluded carbon sequestration in marine units of the NPS, as well as in abiotic pathways, Alaska, and some small park holdings. We have not studied the wider range of other ecosystem services such as watershed protection. The full range of ecosystem services provided by the NPS system would almost certainly contribute a far higher dollar amount.

\footnotetext{
${ }^{41}$ Department of the Interior. "National Park Service Fiscal Year 2015 Budget Justifications." (2014) The budget here is appropriated funds for regular operations, excluding one-time funding for specific park emergencies.
} 
NPS' actual total operations are funded through a complex mix of sources (including federally appropriated funds, income from concession fees and private contributions) and in-kind donations, including the donated efforts of more than 200,000 volunteers. The federally funded portion of the NPS budget has been declining in real terms for the past decade, and is $9 \%$ below the enacted levels of a decade ago. ${ }^{42}$ Due to the NPS's dual mission of stewardship and public recreation, much of the NPS spending is by necessity devoted to activities related to its visitors, including ranger interpretation, visitor centers, visitor safety, visitor amenities (such as trails, signs, displays, restrooms, drinking fountains, etc.), and basic annual maintenance. Mounting budget pressure has forced NPS to delay capital maintenance, cut staff, and defer investments in resource protection. The federally appropriation specifically designated purely for "resource stewardship" in 2014 was only \$329 million - less than half of what NPS units produce directly in vegetative carbon offsets.

Of course, much of this sequestration occurs naturally. We do not have an estimate of how much of the carbon sequestration benefits depend on active NPS management and inputs, Certainly some of the carbon sequestration benefits would be lost as some of these lands would be developed for resorts (e.g., hotel complexes) or even mined or logged or were neglected by owners who were not dedicated to protecting the natural capital in the acreage.

Figure 2: Baseline Carbon Sequestration in CONUS NPS units by type.

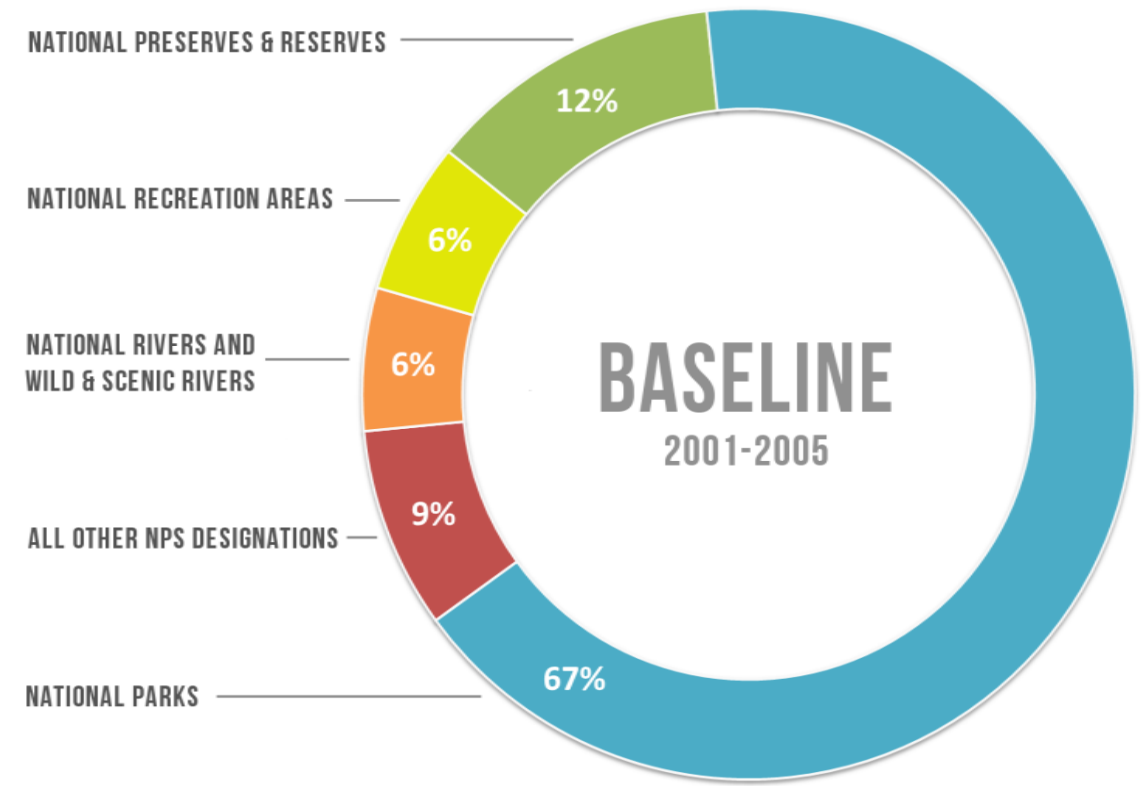

17.5 MILLION METRIC TONS

${ }^{42}$ National Parks Conservation Association, "National Park Service Budget: Parks are popular and economically important; after reduced funding, they need a more adequate FY15 investment for 2016 Centennial," March 11, 2014. 


\section{Nationwide Assessment: Looking Into the Future}

As a second step, we estimated the present value of future NPS carbon sequestration. We utilized the same methodology as the baseline estimate reported above, except this time using the predicted average carbon sequestration rates for the period 2006-2050. In order to keep the two estimates comparable, we kept the same restrictions and classification scheme of NPS units as the baseline. One important methodological point to note, however, is that the future estimates show the average annual NECB for the period 2006-2050, not just the NECB for the year 2050. This makes the attribution of economic values much more difficult, because the SCC cost increases non-linearly with time. While the same approach is used for the baseline period 2001-2005, the time period is much shorter and the practical effect of this approach is negligible. As a result, dollar values have not been applied to the future predictions. Instead, we provide the future estimated tonnage as a basis for comparison.

Reporting volume rather than value addresses an additional complicating factor. Where the overall tonnage of carbon sequestered by the NPS decreases over time, but price increase in the SCC more than offsets the decline, reporting the results in dollars may mask decreases in absolute sequestration. Reporting future estimates as tonnages makes it easier to assess progress toward a climate stabilization goal.

Predicted future carbon sequestration rates (NECBS) are generally lower than baseline rates because the climate is expected to warm and to become more variable in the future, placing increased stress on vegetation from both hotter temperatures and less predictable precipitation. Such stresses will translate into lower vegetative growth rates because vegetation has adapted to its environment over time and cannot in general adapt easily or quickly to different temperature and water regimes. ${ }^{43}$ Drier, hotter summers also increase the potential for wildfires. In addition to releasing large amounts of carbon back into the atmosphere during the actual fire, changes in fire frequency can lower the long-term carbon sequestration rate because very young forests often have lower NECBs than middle-aged and mature forests.

Overall, there is a wide and somewhat unpredictable future trajectory. Our best estimate is that these variables will result on average in 0.2 metric tons $\mathrm{CO}_{2}$ per acre less of carbon sequestration when averaged over all national park acres in this study, in the period 2006 through 2050.

Future predictions are summarized below in Table 3 and are listed unit-by-unit in Appendix 2. Baseline estimates from Table 2 are duplicated in order to make comparison easier.

\footnotetext{
${ }^{43}$ For example, cacti have evolved a special photosynthesis pathway which allows them to open pores in their leaves and surfaces only at night for gas exchange, reducing evaporative water loss to the atmosphere and allowing them to thrive in dry environments. Such metabolic mechanisms are not available to many plants that have evolved in climates with abundant water, leaving them unprepared for periods of increased drought.
} 
Table 3: Carbon sequestration estimates in CONUS NPS units based on 2006-2050 future predictions.

\begin{tabular}{|c|c|c|c|}
\hline \multirow{3}{*}{$\begin{array}{c}\text { NPS } \\
\text { Unit Type }\end{array}$} & \multicolumn{3}{|c|}{ Baseline 2001-2005 Estimates } \\
\hline & Min & Average & Max \\
\hline & \multicolumn{3}{|c|}{ Million Metric Tons of $\mathrm{CO}_{2}$} \\
\hline Parks & 2.92 & 11.68 & 19.63 \\
\hline $\begin{array}{c}\text { Preserves \& } \\
\text { Reserves }\end{array}$ & 0.36 & 2.17 & 3.56 \\
\hline $\begin{array}{c}\text { Recreation } \\
\text { Areas }\end{array}$ & 0.05 & 1.12 & 2.16 \\
\hline $\begin{array}{c}\text { Rivers \& Wild } \\
\text { \& Scenic } \\
\text { Rivers }\end{array}$ & 0.51 & 1.05 & 1.44 \\
\hline Subtotal & 3.84 & 16.02 & 26.79 \\
\hline $\begin{array}{c}\text { Lakeshores \& } \\
\text { Seashores }\end{array}$ & 0.23 & 0.54 & 0.73 \\
\hline Monuments & -0.09 & 0.34 & 0.76 \\
\hline Parkways & 0.12 & 0.26 & 0.37 \\
\hline $\begin{array}{l}\text { Historical } \\
\text { Parks }\end{array}$ & 0.06 & 0.17 & 0.25 \\
\hline $\begin{array}{c}\text { Battlefields, } \\
\text { Battlefield } \\
\text { Sites, \& } \\
\text { Military } \\
\text { Parks }\end{array}$ & 0.04 & 0.11 & 0.16 \\
\hline $\begin{array}{c}\text { Other NPS } \\
\text { Designations }\end{array}$ & 0.02 & 0.04 & 0.06 \\
\hline Historic Sites & 0.01 & 0.02 & 0.03 \\
\hline Memorials & 0 & 0 & 0 \\
\hline Grand Total & 4.24 & 17.50 & 29.16 \\
\hline
\end{tabular}

\begin{tabular}{|c|c|c|}
\hline \multicolumn{3}{|c|}{ Future 2006-2050 Predictions } \\
\hline Min & Average & Max \\
\hline \multicolumn{3}{|c|}{ Million Metric Tons of $\mathrm{CO}_{2}$} \\
\hline-0.18 & 7.82 & 14.82 \\
\hline 0.07 & 1.70 & 2.78 \\
\hline-0.14 & 0.60 & 1.31 \\
\hline 0.07 & 0.81 & 1.39 \\
\hline-0.17 & 10.93 & 20.29 \\
\hline 0.01 & 0.48 & 0.78 \\
\hline-0.06 & 0.21 & 0.47 \\
\hline 0.02 & 0.19 & 0.33 \\
\hline 0 & 0.12 & 0.21 \\
\hline 0 & 0.08 & 0.14 \\
\hline 0 & 0.03 & 0.06 \\
\hline 0 & 0.01 & 0.02 \\
\hline 0 & 0.01 & 0.01 \\
\hline-0.21 & 12.05 & 22.31 \\
\hline
\end{tabular}

The key assumptions in the future NECBs are that the climate is warming along the trendlines identified by the UN Intergovernmental Panel on Climate Change, that consequently the incidence of destructive fires in NPS units will increase, and that there will be no fundamental changes to NPS ecosystem management in response to these environmental changes. Of course, it is likely that NPS will adopt new approaches to respond to these threats. However, based on the NECB assumptions the total sequestration on all NPS units in the CONUS from 2006-2050 is predicted to be on average just over 12.0 million metric tons of carbon dioxide, a $>30 \%$ drop in sequestration capacity over the 2001-2005 baseline estimates. 
The NECB's worst-case future scenario is extremely unlikely; it assumes a sharp rise in global temperatures, a "status quo" set of policies at NPS, and it fails to incorporate into its model that certain ecosystem shifts due to climate change may alter boundaries in ways that do not reduce net carbon sequestration. For example, an acre of unhealthy forest may become an acre of healthy meadow. In this scenario, NPS' stock of accumulated carbon in plants and soils is released into the atmosphere through fires, desertification, and other means, making NPS a net emitter over the period 2006-2050 unless it is able to take climate mitigation actions.

As shown in Table 3 the overall distribution of sequestration across unit types is predicted to remain virtually unchanged despite the smaller size of the overall pie. However, this way to cut the data masks important underlying differences in the sequestration capacity of NPS units. As can be seen in Table 4, losses in ecosystem carbon sequestration capacity are not level across all ecoregion types. ${ }^{44}$ The loss of capacity is spread evenly across most regions except for the Mississippi Alluvial and Southeast Coastal Plains, where sequestration remains more or less unchanged. Large losses occur in the Warm Deserts, which is the only ecoregion to become a net emitter based on future (2006-2050) average predictions. Additional water and heat stress in an already marginal environment may be the cause of this reversal.

44 These ecoregions are the same as the ecoregions mapped in Figure 1. 
Table 4: Baseline (2001-2005) and Future (2006-2050) average predicted carbon sequestration (in metric tons of $\mathrm{CO}_{2}$ ) broken out by ecoregion. (Million Metric Tons of $\mathrm{CO}_{2}$ )

\begin{tabular}{ccccc} 
& $\begin{array}{c}\text { Baseline } \\
\text { Average }\end{array}$ & $\begin{array}{c}\text { Future } \\
\text { Average }\end{array}$ & $\begin{array}{c}\text { Volume } \\
\text { Change }\end{array}$ & $\begin{array}{c}\text { \% of total } \\
\text { change }\end{array}$ \\
\hline Atlantic Highlands & 0.07 & 0.07 & -0.01 & $0 \%$ \\
\hline Central USA Plains & 0.00 & 0.00 & 0.00 & $0 \%$ \\
\hline Cold Deserts & 0.77 & 0.58 & -0.19 & $4 \%$ \\
\hline $\begin{array}{c}\text { Mississippi Alluvial and } \\
\text { SE Coastal Plains }\end{array}$ & 3.59 & 3.49 & -0.10 & $2 \%$ \\
\hline $\begin{array}{c}\text { Marine West Cost } \\
\text { Forest }\end{array}$ & 0.79 & 0.70 & -0.09 & $2 \%$ \\
\hline $\begin{array}{c}\text { Mediterranean } \\
\text { California }\end{array}$ & 0.34 & 0.23 & -0.11 & $2 \%$ \\
\hline Mixed Wood Plains & 0.30 & 0.29 & -0.02 & $0 \%$ \\
\hline Mixed Wood Shield & 0.55 & 0.53 & -0.02 & $0 \%$ \\
\hline $\begin{array}{c}\text { Ozark, Ouachita- } \\
\text { Appalachian Forests }\end{array}$ & 2.61 & 1.90 & -0.71 & $13 \%$ \\
\hline $\begin{array}{c}\text { Great Plains } \\
\text { Southeastern USA } \\
\text { Plains }\end{array}$ & 0.19 & 0.26 & 0.07 & $1 \%$ \\
\hline Warm Deserts & 1.00 & 0.74 & -0.26 & $5 \%$ \\
\hline Western Cordillera & 2.05 & -0.05 & -2.10 & $39 \%$ \\
\hline & 5.21 & 3.31 & -1.91 & $35 \%$ \\
\hline
\end{tabular}

The estimates in Table 4 reinforce the need to examine the spatial and temporal heterogeneity in carbon sequestration rates across the NPS in order to understand how to manage and intervene most effectively in the future in order to preserve this ecosystem service. The two largest areas of potential concern suggested by this analysis-forests of the Western Cordilla and the deserts of the Southwest-are distinct environments whose predicted decline in ecosystem service capacity by 2050 is likely the result of different environmental forcing factors. To protect this ecosystem service, each area will require a customized approached to ecosystem intervention, underscoring the spatially heterogeneous nature of climate change impacts. There is no one-size-fits-all solution and further research is needed by the NPS and others in order to understand our ability to manage this and other ecosystem services for public benefit. 


\section{Preserving Future Carbon Sequestration Capacity}

Much of the impact of climate change will be difficult if not impossible for humans to reverse. However it is likely that NPS action could mitigate some of the decline in ecosystem services on lands it controls. NPS has a complicated challenge given its dual mission to promote recreation as well as to protect ecosystems. For example, the agency needs to balance its efforts to protect the Giant Sequoias in Kings Canyon and Sequoia National Parks with its mission to enable people to see these great trees. As evidence of this, NPS has recently needed to renovate trails in some groves when it found that foot traffic compacting soil in root zones was negatively impacting the ability of the trees to absorb water and nutrients.

If we assume, to be conservative, that NPS actions could prevent $20 \%$ of the predicted decline in sequestration capacity, an additional 545,008 metric tons of $\mathrm{CO}_{2}$ per year would be stored annually over the period 2006-2050. At the present-day social cost of carbon this represents $\$ 22$ million in annual carbon damages avoided (e.g., benefits received).

\section{What can the NPS do to preserve carbon sequestration capacity for the future?}

The NPS already performs many types of activities that help improve the health of ecosystems in its care, such as manual removal and controlled burns among other measures. However there are three broad areas where increased NPS efforts are likely to make a positive impact on carbon sequestration: managing invasive species, recreation management and education, and improved science-based understanding. Additional funding would enable NPS to increase efforts in all three categories with an important potential payback in terms of higher carbon capture.

\section{Managing Invasive Species.}

Ecosystems in the United States are under threat from hundreds of introduced pests that pose significant risks to ecosystem health and stand to make a potentially large negative impact on carbon sequestration capacity. ${ }^{45,46}$ This is both because invasive species kill or displace native species, potentially lowering carbon sequestration capacity, and because some invasive species increase the frequency and severity of wildfires by providing fuel. ${ }^{47}$ More invasive species are likely to be introduced into the United States in the future, making this a growing problem.

\footnotetext{
45 Alan Hall. "Costly Interlopers_-Introduced species of animals, plants and microbes cost the US \$123 billion a year." InFocus Feb 14 (1999).

${ }^{46}$ Heather Charles and Jeffrey S. Dukes. "Impacts of invasive species on ecosystem services." Biological invasions .Springer, 2007. 217-237.

${ }^{47}$ For example, introduced species such as Buffel Grass (Pennisetum ciliare) provide highly-combustible fuel that increases the intensity and frequency of fires in fragile environments such as Saguaro National Park, compromising the ability of native vegetation to successfully regenerate. Elsewhere, Balsam woolly adelgid is an introduced pest that kills Fraser and Balsam firs, including nearly all of the Fraser Firs in Great Smoky Mountains National Park (Figure 3). Significant impacts from the pest have also been felt in the Pacific Northwest.
} 
In some cases, infestations do not have solutions, and NPS works to fight the spread on infestations and ensure that restoration remains possible in the future. For example, in the case of highly destructive diseases, such as Balsam woolly adelgid, the NPS also works to preserve genetic diversity of the threatened species-Balsam Firs- by collecting seeds and plants, and maintaining them off-site and in seed banks so that the Balsam fir can be reintroduced if and when a permanent solution is discovered. Figure 3 shows an example of the damage invasive species can inflict on forest ecosystems.

Figure 3: A "Ghost Forest" of dead Fraser firs (gray) among living broadleaf deciduous trees (green) in Great Smoky Mountains National Park. The deaths are caused by the invasive Balsam Woolly Adelgid; currently no known feasible large-scale control methods exist. The NPS maintains some small refuge areas where intensive insect control is practiced in order to provide seed populations and maintain genetic diversity if a permanent solution is ever found. Photo by Tara Varghese.

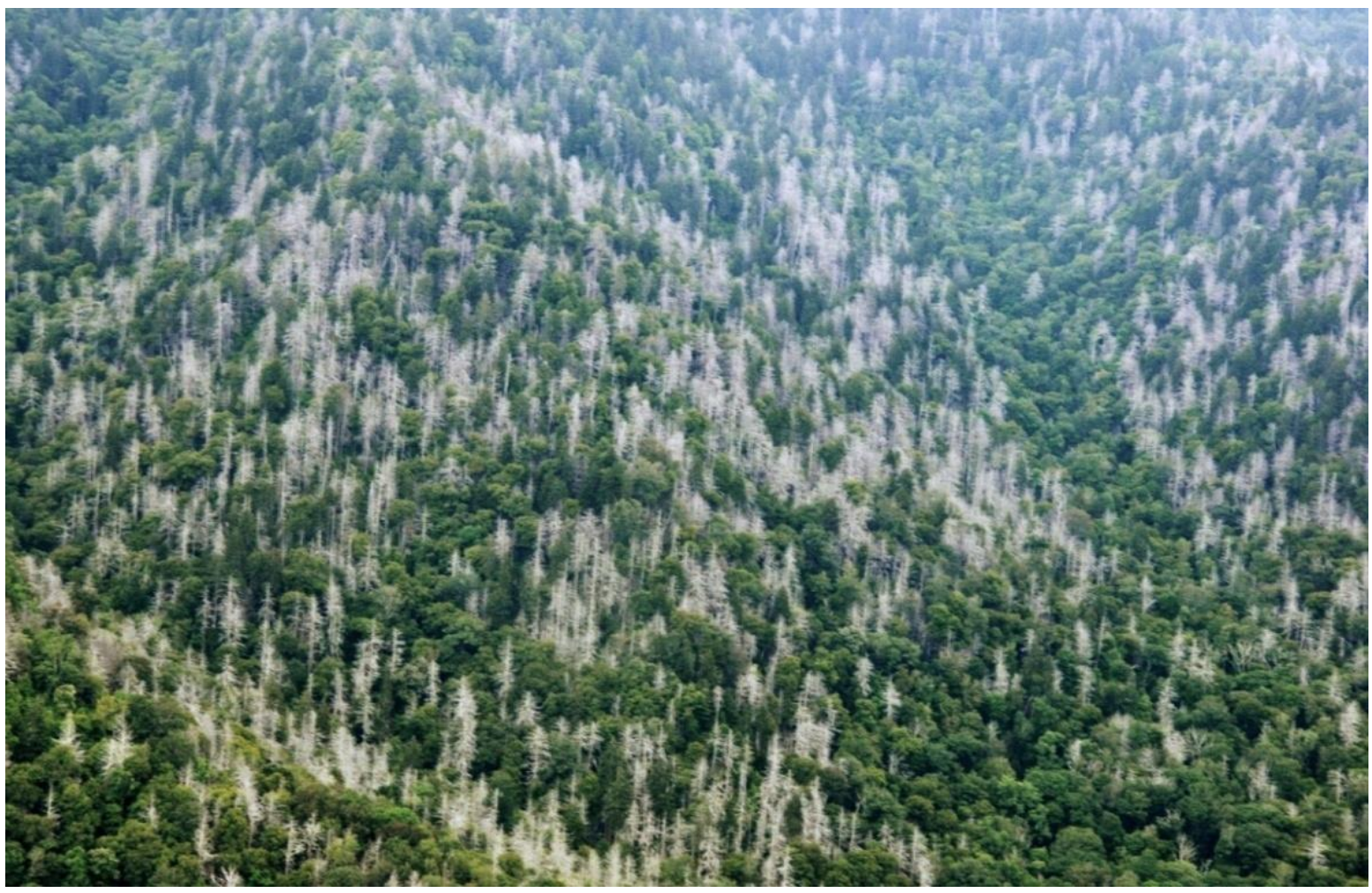

When solutions do exist, NPS sometimes actively works to restore ecosystem to their pre-infestation quality. For example, tamarix, or saltcedar, is an invasive shrub or small tree common across much of the American southwest. Tamarix can prevent establishment of native plant species, consume more of the regions' scarce water resources than native plants, increase the chance and severity of wildfires due to its 
copious litter droppings, alter riparian habit decreasing suitability for aquatic species, and decrease visitation values by making navigation difficult and blocking views. While numerous control options are under study, one highly-effective (although labor intensive) management technique to reverse the infestation is manual removal of plants in affected areas. Management of tamarix in the Lake Mead National Recreation Area began in 1988. Since 2000, Lake Mead National Recreation Area has deployed teams of exotic plant management teams to help control tamarix as well as other invasive species. To date, tamarix have been cleared from more than a dozen drainages within the recreation area, with cleared area monitored every 1-3 years to ensure they remain uninfested and native plants reestablish on cleared areas. ${ }^{48}$

\section{Recreation Management \& Education.}

Managing the human impact on parks is another way the NPS works to maintain carbon sequestration capacity. By limiting access to sensitive areas, vulnerable vegetation is protected from trampling, fragile soils are preserved, and erosion into wetlands and rivers is avoided. NPS currently devotes considerable resources to protecting these areas, through trail maintenance, visitor education, signage, designated campsites, construction of barriers, fire prevention, and other efforts.

For example, Everglades National Park is currently finalizing a seagrass management plan. ${ }^{49}$ Florida Bay is a popular place for recreational boating and fishing. However, due to the shallowness of the Bay (less than 4 feet on average) recreational boaters familiar with much deeper water common in coastal areas and lakes elsewhere pose a significant threat to seagrass communities on the floor of Florida Bay. Such seagrass communities are an important nursery environment for aquatic life as well as a significant carbon sink. At least 325 miles of propeller scars, which form when boat propellers scrape against the bay bottom, have been mapped by the NPS (although at least one study indicates the total estimate for the entire bay may be as much as 10 times greater). ${ }^{50}$ Management options explored in the management plan that will improve and retain carbon storage capacity include improved signage for navigable channels within the park, improved boater education so that visitors and recreational boaters can understand their role in preserving the park's unique environments, and temporary closure and restoration of damaged areas.

However, over the past decade staff reductions and reduced funding for maintenance and mitigation projects (such as the seagrass plan) have contributed to a backlog of challenges. The increasing risks that are expected due to climate changes will make it

\footnotetext{
${ }^{48}$ National Park Service. 2005. Plant Conservation Alliance Alien Plant Working Group. Fact Sheet: Saltcedar. Available on the Internet at: http://www.nps.gov/plants/alien/fact/pdf/tama1.pdf.

${ }^{49}$ National Park Service. Florida Bay, Everglades National Park Draft Seagrass Habitat Restoration Mangement Plan. P11PC21000 Vol. , 2013.

${ }^{50}$ National Park Service. 2013.Florida Bay, Everglades National Park Draft Seagrass Habitat Restoration Management Plan.
} 
even more important in the future for NPS to mitigate the harm that visitation can introduce into fragile ecosystems.

\section{Improving Science-Based Understanding \& Research.}

In many cases, even when a problem is identified, scientists simply do not have enough information to know how to best preserve what we have. Famously, poor fire management practices of the past century focused on suppressing all fires and led to the conditions that fuel intense mega-fires today. These fires have seriously damaged many national parks and the ecosystem services they provide, above and beyond the normal disturbances expected from a natural fire regime. Research can document existing vegetation patterns, so that even if solutions cannot be found today, at some point in the future the impacted areas can be restored to their original condition. This is especially true when many ecosystems are venturing into unknown climate territory, where a detailed understanding of how these ecosystems operate is our best chance of ensuring their survival.

The NPS documents existing park inventories and often acts as a locus for research. For example, the South Florida Natural Resources Center is working to locate or create the technical information needed to make informed decisions as part of the multi-billion dollar Comprehensive Everglades Restoration Plan. Determining the water quantity and quality needed to maintain the health of the everglades will help ensure against oxidation of accumulated wetlands soils which occurs when soils dry out, and prevent associated $\mathrm{CO}_{2}$ emissions. 


\section{Applicability to Other Federally-Owned Lands}

To what extent is the method developed here applicable to other federally controlled lands? Since ownership goals vary by controlling body, the applicability of this method also varies widely. While the method is highly applicable to the Fish \& Wildlife Service and the U.S. Forest Service, it is less suited for use on Bureau of Land Management lands, and not suited for use on Department of Defense lands.

\section{Fish \& Wildlife Service (FWS).}

The method outlined in this paper is well suited to determining carbon sequestration on lands administered by the FWS. This is primarily because the FWS mission is largely concerned with conservation and restoration, while recreational and other uses (timber harvesting, energy development) are allowed only where these are compatible with conservation and restoration goals. ${ }^{51,52}$ The FWS itself has also recognized the applicability of the LandCarbon data, cooperating with the LandCarbon team on data collection efforts and investigating the potential for LandCarbon data to be used to target high-priority parcels for acquisition and restoration. ${ }^{53}$ FWS also has prior experience with carbon credit schemes, having used public-private partnerships based on carbon credit value created by habitat restoration as a means for funding projects, with particular success in the Mississippi River Valley region. ${ }^{54}$

One area where this method may be valuable is the recently designated 89 million acre Papahānaumokuākea Marine National Monument, which is under the administration of the Fish and Wildlife Service, the National Oceanic and Atmospheric Administration, and the Hawai'i Department of Land and Natural Resources. The method used in this paper could be applied to this marine resource if a peer-reviewed set of NECBs for marine ecosystems were available. If such a data source were available, FWS may be able to demonstrate a large potential ecosystem service benefit, given the high productivity and large size of the monument.

\section{U.S. Forest Service (USFS).}

While the method in this paper is applicable to Forest Service lands, the U.S. Forest Service has already developed its own detailed carbon sequestration methodologies including sequestration rates for 51 forest types in 10 different regions of the country. These estimates were developed as part of the forest inventory and analysis national program, a long-running program providing technical guidance on how to assess the

\footnotetext{
${ }^{51}$ U.S. Fish \& Wildlife Service. National Wildlife Refuges System, 2014.

http://www.fws.gov/refuges/about/mission.html.

52 Ross W. Gorte, et al. Federal Land Ownership: Overview and Data., 2012.

${ }^{53}$ U.S. Fish \& Wildlife Service. Biological Carbon Sequestration Accomplishments Report 2009-2013. U.S. Fish \& Wildlife Service; National Wildlife Refuge System, May 2014.
} 
health of the nation's forests. ${ }^{55}$ Parts of the detailed data already collected by the U.S. Forest Service were used by LandCarbon either directly in their modeling or as a comparison to ground-truth model outputs. Assessments by the U.S. Forest Service include the effects of harvesting on forest health and growth rate, which do not occur on National Park Service Lands.

\section{Bureau of Land Management (BLM).}

The BLM's mission, "to sustain the health, diversity, and productivity of the public lands" encompasses a wide range of activities, from the livestock grazing, mining and coal leases, timberlands harvest agreements, and renewable energy project permitting to conservation, restoration, and outdoor recreation. ${ }^{56}$ While some of these roles support long-term carbon sequestration, others may promote degradation of landscapes or release of stored carbon. As a result, the methodology developed here may be applicable to only a subset of BLM holdings, but is not likely applicable to all lands managed by BLM.

\section{Department of Defense (DoD).}

The method described here may not be appropriate for DoD lands. While the DoD does have a Natural Resources Program, it generally aims to conserve lands only to the degree required by law (for threatened or endangered species) or to the extent needed to maintain a realistic combat simulation environment. Maintaining the healthy functioning of ecosystems is not a listed priority. As a result, the long-term carbon storage capacity of DoD lands is not best reflected by the method outlined in this paper.

\footnotetext{
55 James E. Smith, et al. "Methods for calculating forest ecosystem and harvested carbon with standard estimates for forest types of the United States." (2006)

${ }^{56}$ U.S. Department of the Interior, Bureau of Land Management. About the BLM, 2012. http://www.blm.gov/wo/st/en/info/About_BLM.html.
} 


\section{Conclusion}

This paper provides an estimate of the economic value created by vegetative carbon sequestration in the major continental units of the National Park Service. It should be viewed as highly conservative in that we focus on only a subset of NPS units and land types and use a moderate and constant discount rate to estimate sequestration capacity.

We have not attempted to attribute this estimate to specific NPS interventions, because there is no existing nationwide inventory of NPS management activities and their associated costs. Additionally, since management actions are taken for a variety of reasons and achieve multiple objectives, it would be difficult to assess what portion of the cost should be assigned to actions preserving and enhancing carbon sequestration. Therefore our output should be viewed as simply the estimated present-day and future tonnage/dollar value of the carbon sequestration occurring on NPS lands under the existing management practices supported by the current budget.

However, the study is significant in four respects.

1. First, it is the first serious study of economic value in NPS units that is related to its stewardship mission, rather than to visitation. There is a large body of literature related to the visitation mission, but the vast activities of the agency related to stewardship, conservation and other functions have never been studied until now.

2. Second, the estimate is significant in relation to the annual federal appropriations for the National Park Service. Our estimate is that value of carbon sequestered in these lands is $\$ 707.86$ million annually. Thus the benefits of just this one single ecosystem service return about $28 \%$ of the NPS budget to the American public. Outside of the budget, another way to think about it is that the 17.5 million metric tons of $\mathrm{CO}_{2}$ sequestered per year in NPS units is equivalent to saving the emissions from the combustion of 2 billion gallons of gasoline per year from being released into the air. ${ }^{57}$

3. Third, the study demonstrates that without greater intervention by NPS, the amount of carbon sequestered in NPS units will decline due to global climate trends. This suggests that additional resources should be dedicated to undertaking mitigation efforts to reduce the rate of decline. An important future analysis would be to compute the incremental land management cost to the NPS maintain the current level of carbon sequestration versus the value of the future loss of future carbon sequestration.

\footnotetext{
57 Another way to visualize 17.5 million metric tons of $\mathrm{CO}_{2}$ sequestered by the NPS units is to think about how many gallons of gasoline would generate the same amount of $\mathrm{CO}_{2}$ emissions if they were used in to power a car. For an average American car using gasoline with a typical amount of ethanol, there are approximately 112.5 gallons of gas consumed for every 1 metric ton of $\mathrm{CO}_{2}$ produced. Using this conversion, 17.5 million metric tons of $\mathrm{CO}_{2}$ is slightly less than 2 billion gallons of gasoline.
} 
4. Fourth, the methodology used to estimate the social benefits of the carbon sequestered in NPS units can be applied to other public lands, including NPS lands in Alaska (when USGS completes its LandCarbon analysis of carbon sequestration) and other federal land management agencies such as the Fish and Wildlife Service, U.S. Forest Service, and NOAA. This will further document the economic benefits of the federal government acting as a responsible environmental steward.

The NPS is an important custodian of our nation's ecosystems, from coral reefs to tundra. This study provides a new appreciation for the importance of the NPS stewardship mission in some of the areas it administers, and we hope our work will stimulate further study of the many additional ecosystem services the agency provides. 


\section{Appendix 1 - NECBs used in this analysis}

Calculated from USGS LandCarbon data.

NECBs used in this study compiled from all the Great Plains, Eastern, and Western USGS Landcarbon Reports.

Please see text for a discussion of how these numbers were calculated.

\begin{tabular}{|c|c|c|c|c|c|c|c|c|c|}
\hline \multirow{3}{*}{$\left(\mathrm{gC} / \mathrm{Yr} / \mathrm{m}^{2}\right)$} & \multicolumn{9}{|c|}{ Baseline: 2001-2005 } \\
\hline & \multicolumn{3}{|c|}{ Forest } & \multicolumn{3}{|c|}{ Grassland } & \multicolumn{3}{|c|}{ Wetland } \\
\hline & Min & Average & Max & Min & Average & Max & Min & Average & Max \\
\hline Atlantic Highlands & 98.7 & 156.2 & 177.5 & 0.0 & 326.8 & 326.8 & 58.6 & 117.1 & 136.6 \\
\hline Central USA Plains & 88.3 & 113.5 & 126.1 & 0.0 & 0.0 & -85.1 & 64.2 & 85.6 & 107.0 \\
\hline Cold Deserts & -15.4 & 32.4 & 80.3 & -4.7 & 10.6 & 26.0 & 0.0 & 64.7 & 129.4 \\
\hline $\begin{array}{l}\text { Mississippi Alluvial and SE } \\
\text { Coastal Plains }\end{array}$ & 25.5 & 170.7 & 262.9 & 0.0 & 31.4 & 52.4 & 37.7 & 130.2 & 191.0 \\
\hline Marine West Cost Forest & 20.1 & 56.5 & 92.9 & 0.0 & 77.1 & 154.1 & 0.0 & 0.0 & 0.0 \\
\hline Mediterranean California & 86.8 & 145.3 & 203.7 & -4.0 & 41.1 & 86.1 & -109.9 & 0.0 & 109.9 \\
\hline Mixed Wood Plains & 91.2 & 141.2 & 152.7 & 44.5 & 44.5 & 89.0 & 61.9 & 86.7 & 99.0 \\
\hline Mixed Wood Shield & 42.5 & 87.7 & 112.2 & 52.7 & 79.0 & 105.4 & 29.6 & 78.5 & 92.4 \\
\hline $\begin{array}{l}\text { Ozark, Ouachita-Appalachian } \\
\text { Forests }\end{array}$ & 83.6 & 155.8 & 209.6 & 0.0 & 51.2 & 76.9 & 38.6 & 154.3 & 231.5 \\
\hline Great Plains & 9.2 & 30.0 & 45.6 & 9.2 & 30.0 & 45.6 & 9.2 & 30.0 & 45.6 \\
\hline Southeastern USA Plains & 68.5 & 169.8 & 257.6 & -8.9 & 53.3 & 88.8 & 80.6 & 207.4 & 288.0 \\
\hline Warm Deserts & -24.7 & 24.7 & 74.2 & -6.7 & 16.6 & 39.9 & 0.0 & 0.0 & 0.0 \\
\hline Western Cordillera & 35.9 & 82.2 & 128.6 & -0.7 & 25.9 & 52.5 & 27.4 & 109.4 & 191.5 \\
\hline
\end{tabular}




\section{Appendix 1 - NECBs used in this analysis}

Calculated from USGS LandCarbon data.

Future: 2006-2050 Average

\begin{tabular}{|c|c|c|c|c|c|c|c|c|c|}
\hline \multirow{2}{*}{$\left(\mathrm{gC} / \mathrm{Yr} / \mathrm{m}^{2}\right)$} & \multicolumn{3}{|c|}{ Forest } & \multicolumn{3}{|c|}{ Grassland } & \multicolumn{3}{|c|}{ Wetland } \\
\hline & Min & Average & $\operatorname{Max}$ & Min & Average & $\operatorname{Max}$ & Min & Average & $\operatorname{Max}$ \\
\hline Atlantic Highlands & 14.5 & 145.5 & 205.4 & 0.0 & 0.0 & 0.0 & 58.5 & 175.6 & 214.7 \\
\hline Central USA Plains & 13.9 & 83.3 & 138.8 & -120.9 & 0.0 & 0.0 & 42.9 & 107.3 & 150.3 \\
\hline Cold Deserts & 8.2 & 43.7 & 79.2 & -5.7 & 2.6 & 10.9 & 0.0 & 45.4 & 90.9 \\
\hline $\begin{array}{c}\text { Mississippi Alluvial and SE } \\
\text { Coastal Plains }\end{array}$ & -32.0 & 139.4 & 248.0 & -7.5 & 11.2 & 22.4 & 32.6 & 128.5 & 184.0 \\
\hline Marine West Cost Forest & -29.1 & 50.9 & 130.9 & 0.0 & 46.0 & 92.0 & 0.0 & 87.0 & 173.9 \\
\hline Mediterranean California & 67.0 & 130.7 & 194.4 & -9.2 & 18.3 & 45.8 & 0.0 & 147.2 & 294.4 \\
\hline Mixed Wood Plains & -8.0 & 131.1 & 216.4 & 0.0 & 0.0 & 48.8 & 34.1 & 119.2 & 153.2 \\
\hline Mixed Wood Shield & -35.0 & 69.1 & 132.6 & 0.0 & 26.2 & 26.2 & 54.5 & 137.9 & 171.9 \\
\hline $\begin{array}{l}\text { Ozark, Ouachita-Appalachian } \\
\text { Forests }\end{array}$ & 16.2 & 113.6 & 192.3 & 0.0 & 26.3 & 26.3 & 37.4 & 149.8 & 187.2 \\
\hline Great Plains & 192.5 & 192.5 & 192.5 & 13.4 & 13.4 & 13.4 & 52.1 & 52.1 & 52.1 \\
\hline Southeastern USA Plains & -16.0 & 110.6 & 231.1 & -9.6 & 28.9 & 67.5 & 80.4 & 214.5 & 264.9 \\
\hline Warm Deserts & 0.0 & 31.1 & 62.2 & -13.6 & -1.9 & 9.8 & 0.0 & 155.3 & 310.6 \\
\hline Western Cordillera & 12.8 & 54.4 & 95.9 & -1.1 & 13.8 & 28.8 & 0.0 & 56.6 & 113.3 \\
\hline
\end{tabular}




\section{Appendix 2 - NPS Unit Carbon Sequestration Estimates}

\section{Ranked NPS Units Sequestering at least $0.5 \%$ of the Baseline Total}

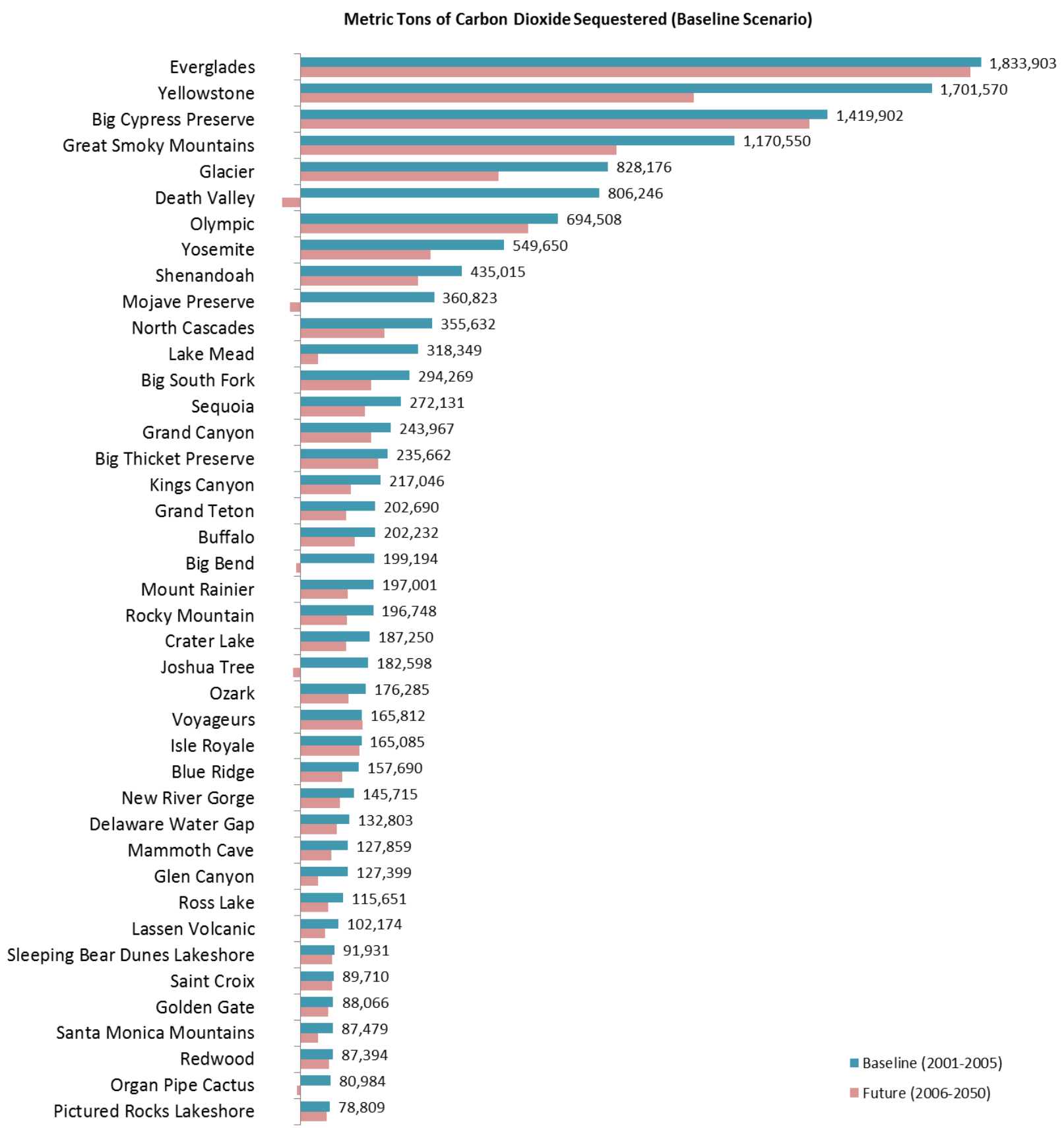

Note: Tonnage reported on graph for baseline estimate.

Note: Lake Mead includes areas now designated as Parashant National Monument. 
Appendix 2 - NPS Unit Carbon Sequestration Estimates

\begin{tabular}{|c|c|c|c|c|c|c|c|}
\hline & & & & Metric Ton & s of Carbon Dioxid & & \\
\hline & Base Average (@\$40.45) & Base Min & Base Average & Base Max & Future Min & Future Average & Future Max \\
\hline National Battlefields, Battlefield Sites, \& Military Parks & $\$ 4,519,315$ & 44,847 & 111,726 & 163,323 & -149 & 78,161 & 144,161 \\
\hline Antietam Battlefield & $\$ 90,846$ & 572 & 2,246 & 3,206 & 119 & 1,397 & 1,936 \\
\hline Big Hole Battlefield & $\$ 16,963$ & 99 & 419 & 739 & 26 & 250 & 474 \\
\hline Brices Cross Roads Battlefield Site & $\$ 68$ & 1 & 2 & 3 & 0 & 1 & 2 \\
\hline Chickamauga \& Chattanooga & $\$ 695,271$ & 8,996 & 17,188 & 23,191 & 1,776 & 12,504 & 20,977 \\
\hline Cowpens Battlefield & $\$ 67,630$ & 628 & 1,672 & 2,543 & -144 & 1,096 & 2,264 \\
\hline Fort Donelson Battlefield & $\$ 49,510$ & 483 & 1,224 & 1,854 & -96 & 812 & 1,660 \\
\hline Fort Necessity Battlefield & $\$ 75,511$ & 986 & 1,867 & 2,515 & 192 & 1,356 & 2,285 \\
\hline Fredericksburg \& Spotsylvania Military Park & $\$ 782,673$ & 7,254 & 19,349 & 29,256 & $-1,007$ & 13,211 & 26,086 \\
\hline Fredericksburg Military Park & $\$ 323$ & -1 & 8 & 13 & -1 & 4 & 10 \\
\hline Gettysburg Military Park & $\$ 202,810$ & 1,222 & 5,014 & 7,748 & -341 & 3,314 & 6,647 \\
\hline Guilford Courthouse Military Park & $\$ 15,980$ & 159 & 395 & 599 & -37 & 257 & 538 \\
\hline Horseshoe Bend Military Park & $\$ 184,404$ & 1,817 & 4,559 & 6,909 & -382 & 3,005 & 6,191 \\
\hline Kennesaw Mountain Battlefield Park & $\$ 259,909$ & 2,520 & 6,425 & 9,759 & -585 & 4,195 & 8,725 \\
\hline Kings Mountain Military Park & $\$ 386,060$ & 3,760 & 9,544 & 14,504 & -912 & 6,199 & 12,971 \\
\hline Manassas Battlefield Park & $\$ 315,068$ & 2,724 & 7,789 & 11,574 & 498 & 6,025 & 10,313 \\
\hline Monocacy Battlefield & $\$ 60,979$ & 285 & 1,508 & 2,350 & -112 & 983 & 1,985 \\
\hline Moores Creek Battlefield & $\$ 5,706$ & 26 & 141 & 215 & -5 & 117 & 193 \\
\hline Pea Ridge Military Park & $\$ 319,447$ & 3,881 & 7,897 & 10,723 & 754 & 5,619 & 9,273 \\
\hline Petersburg Battlefield & $\$ 275,095$ & 2,539 & 6,801 & 10,335 & -537 & 4,497 & 9,197 \\
\hline Richmond Battlefield Park & $\$ 121,575$ & 1,117 & 3,006 & 4,485 & 71 & 2,233 & 4,012 \\
\hline Shiloh Battlefield & $\$ 318,249$ & 3,713 & 7,868 & 10,819 & 968 & 5,989 & 9,495 \\
\hline Stones River Battlefield & $\$ 33,613$ & 255 & 831 & 1,279 & -79 & 535 & 1,115 \\
\hline Tupelo Battlefield & $\$ 0$ & 0 & 0 & 0 & 0 & 0 & 0 \\
\hline Vicksburg Military Park & $\$ 127,413$ & 471 & 3,150 & 4,853 & -578 & 2,566 & 4,555 \\
\hline Wilson's Creek Battlefield & $\$ 114,213$ & 1,339 & 2,824 & 3,849 & 263 & 1,994 & 3,256 \\
\hline National Historic Site & $\$ 836,723$ & 7,281 & 20,685 & 31,138 & 3,842 & 13,681 & 22,034 \\
\hline Allegheny Portage Railroad & $\$ 91,562$ & 1,206 & 2,264 & 3,046 & 234 & 1,647 & 2,783 \\
\hline Andersonville & $\$ 33,736$ & 291 & 834 & 1,271 & -62 & 553 & 1,123 \\
\hline Andrew Johnson & $\$ 408$ & 4 & 10 & 14 & 1 & 7 & 11 \\
\hline Bent's Old Fort & $\$ 11,783$ & 90 & 291 & 444 & 259 & 259 & 259 \\
\hline Boston African American & $\$ 0$ & 0 & 0 & 0 & 0 & 0 & 0 \\
\hline Brown V Board Of Education & $\$ 0$ & 0 & 0 & 0 & 0 & 0 & 0 \\
\hline Carl Sandburg Home & $\$ 20,956$ & 274 & 518 & 698 & 53 & 376 & 634 \\
\hline Charles Pinckney & $\$ 73$ & 1 & 2 & 3 & 0 & 1 & 2 \\
\hline Clara Barton & $\$ 45$ & 0 & 1 & 2 & 0 & 1 & 2 \\
\hline Edgar Allan Poe & $\$ 0$ & 0 & 0 & 0 & 0 & 0 & 0 \\
\hline Eisenhower & $\$ 12,421$ & 24 & 307 & 482 & -7 & 210 & 395 \\
\hline Eleanor Roosevelt & $\$ 11,341$ & 189 & 280 & 318 & 9 & 272 & 437 \\
\hline Eugene O'Neill & $\$ 251$ & 2 & 6 & 10 & 2 & 5 & 8 \\
\hline Ford's Theatre & $\$ 20,096$ & 200 & 497 & 754 & -46 & 324 & 676 \\
\hline Fort Bowie & $\$ 9,945$ & -110 & 246 & 602 & -186 & -2 & 181 \\
\hline Fort Davis & $\$ 5,171$ & -70 & 128 & 325 & -65 & 47 & 160 \\
\hline Fort Laramie & $\$ 11,807$ & 90 & 292 & 445 & 249 & 249 & 249 \\
\hline Fort Larned & $\$ 4,718$ & 36 & 117 & 178 & 66 & 66 & 66 \\
\hline Fort Point & $\$ 642$ & 8 & 16 & 24 & 6 & 13 & 21 \\
\hline Fort Raleigh & $\$ 11,125$ & 43 & 275 & 423 & -43 & 226 & 395 \\
\hline Fort Scott & $\$ 0$ & 0 & 0 & 0 & 0 & 0 & 0 \\
\hline Fort Smith & $\$ 310$ & 3 & 8 & 11 & 2 & 7 & 9 \\
\hline Fort Union Trading Post & $\$ 3,575$ & 27 & 88 & 135 & 116 & 116 & 116 \\
\hline Fort Vancouver & $\$ 185$ & 0 & 5 & 9 & 0 & 3 & 5 \\
\hline Frederick Douglas Home & $\$ 0$ & 0 & 0 & 0 & 0 & 0 & 0 \\
\hline Frederick Law Olmsted & $\$ 0$ & 0 & 0 & 0 & 0 & 0 & 0 \\
\hline Friendship Hill & $\$ 53,752$ & 696 & 1,329 & 1,792 & 135 & 962 & 1,618 \\
\hline Golden Spike & $\$ 16,364$ & -179 & 405 & 989 & -215 & 101 & 417 \\
\hline Grant-Kohrs Ranch & $\$ 26,565$ & 202 & 657 & 1,000 & 456 & 456 & 456 \\
\hline Hampton & $\$ 2,131$ & 21 & 53 & 80 & -5 & 34 & 72 \\
\hline Harry S Truman & $\$ 0$ & 0 & 0 & 0 & 0 & 0 & 0 \\
\hline Herbert Hoover & $\$ 1,911$ & 15 & 47 & 72 & 21 & 21 & 21 \\
\hline Home Of Franklin D Roosevelt & $\$ 16,023$ & 269 & 396 & 461 & -11 & 345 & 597 \\
\hline Hopewell Furnace & $\$ 68,827$ & 631 & 1,702 & 2,582 & -117 & 1,139 & 2,297 \\
\hline Hubbell Trading Post & $\$ 938$ & -10 & 23 & 57 & -12 & 6 & 24 \\
\hline James A. Garfield & $\$ 0$ & 0 & 0 & 0 & 0 & 0 & 0 \\
\hline Jimmy Carter & $\$ 3,570$ & 19 & 88 & 138 & -11 & 54 & 117 \\
\hline John F Kennedy & $\$ 0$ & 0 & 0 & 0 & 0 & 0 & 0 \\
\hline John Muir & $\$ 20,389$ & 247 & 504 & 761 & 179 & 418 & 657 \\
\hline Knife River Indian Villages & $\$ 23,459$ & 178 & 580 & 883 & 783 & 783 & 783 \\
\hline Lincoln Home & $\$ 0$ & 0 & 0 & 0 & 0 & 0 & 0 \\
\hline Little Rock Central High School & $\$ 0$ & 0 & 0 & 0 & 0 & 0 & 0 \\
\hline Longfellow & $\$ 0$ & 0 & 0 & 0 & 0 & 0 & 0 \\
\hline Maggie L. Walker & $\$ 0$ & 0 & 0 & 0 & 0 & 0 & 0 \\
\hline Manzanar & $\$ 6,186$ & -56 & 153 & 361 & -65 & 53 & 172 \\
\hline Martin Luther King Jr. & $\$ 0$ & 0 & 0 & 0 & 0 & 0 & 0 \\
\hline Martin Van Buren & $\$ 440$ & 11 & 11 & 22 & 0 & 0 & 12 \\
\hline Mary Bethune House & $\$ 0$ & 0 & 0 & 0 & 0 & 0 & 0 \\
\hline Minidoka Internment & $\$ 238$ & -3 & 6 & 14 & -3 & 1 & 6 \\
\hline Minuteman Missile & $\$ 120$ & 1 & 3 & 5 & 1 & 1 & 1 \\
\hline Nicodemus & $\$ 44$ & 0 & 1 & 2 & 0 & 0 & 0 \\
\hline Ninety Six & $\$ 82,144$ & 761 & 2,031 & 3,052 & -39 & 1,440 & 2,727 \\
\hline Pennsylvania Avenue & $\$ 0$ & 0 & 0 & 0 & 0 & 0 & 0 \\
\hline Peterson House & $\$ 10,172$ & 6 & 251 & 399 & -12 & 166 & 322 \\
\hline Sagamore Hill & $\$ 5,289$ & 48 & 131 & 198 & -8 & 88 & 176 \\
\hline Saint Paul's Church & $\$ 0$ & 0 & 0 & 0 & 0 & 0 & \\
\hline
\end{tabular}


Appendix 2 - NPS Unit Carbon Sequestration Estimates

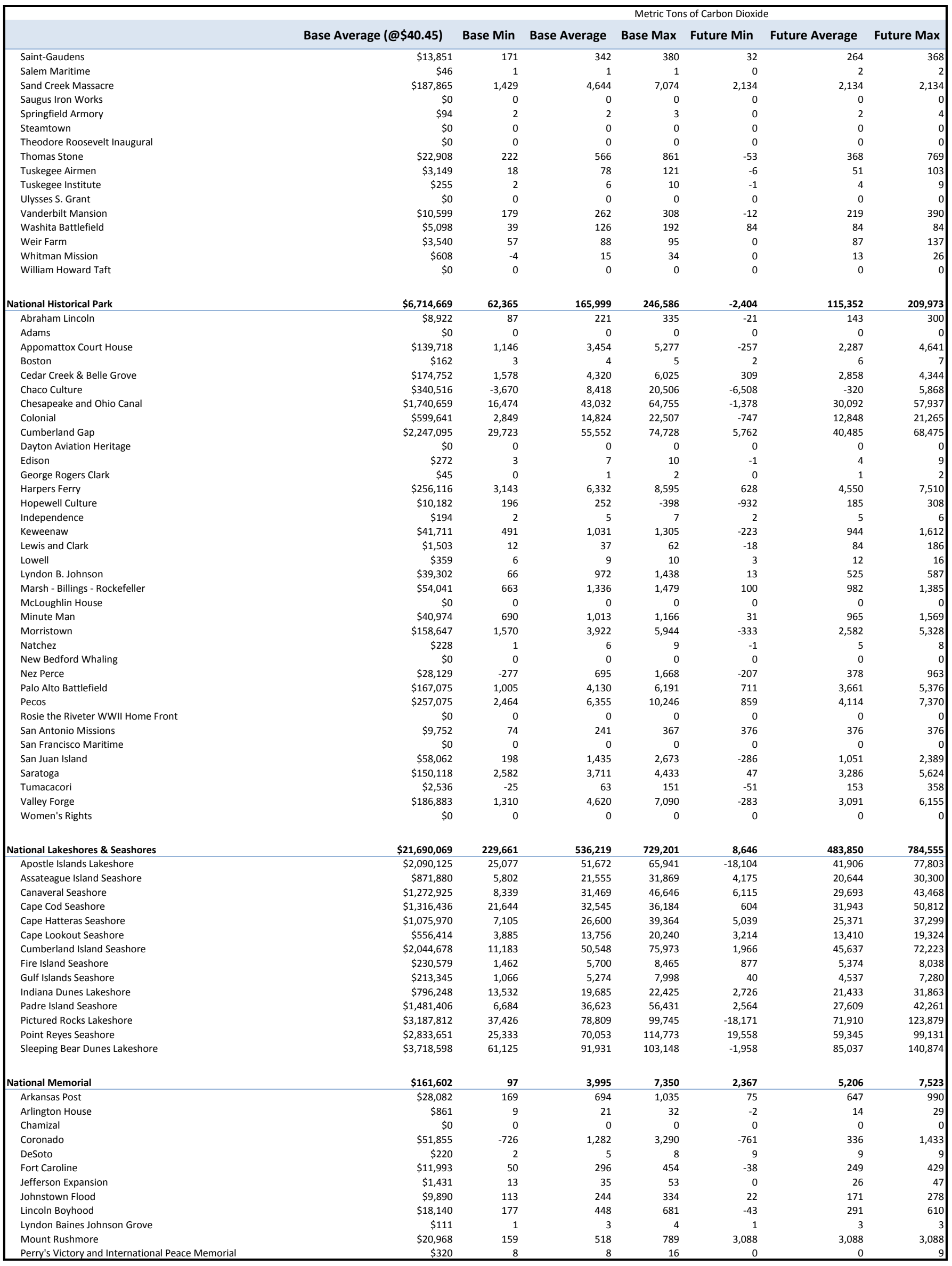


Appendix 2 - NPS Unit Carbon Sequestration Estimates

\begin{tabular}{|c|c|c|c|c|c|c|c|}
\hline & & & & Metric Ton & s of Carbon Dioxic & & \\
\hline & Base Average (@\$40.45) & Base Min & Base Average & Base Max & Future Min & Future Average & Future Max \\
\hline Roger Williams & $\$ 0$ & 0 & 0 & 0 & 0 & 0 & 0 \\
\hline Thaddeus Kosciuszko & $\$ 0$ & 0 & 0 & 0 & 0 & 0 & 0 \\
\hline Theodore Roosevelt Island & $\$ 8,189$ & 80 & 202 & 293 & 35 & 175 & 266 \\
\hline Wright Brothers & $\$ 9,541$ & 42 & 236 & 360 & -19 & 197 & 331 \\
\hline National Monument & $\$ 13,741,000$ & $-87,981$ & 339,703 & 762,104 & $-60,796$ & 208,083 & 471,508 \\
\hline Agate Fossil Beds & $\$ 52,807$ & 402 & 1,305 & 1,988 & 707 & 707 & 707 \\
\hline Alibates Flint Quarries & $\$ 23,970$ & 182 & 593 & 903 & 377 & 377 & 377 \\
\hline Aztec Ruins & $\$ 2,558$ & -17 & 63 & 144 & -21 & 27 & 74 \\
\hline Bandelier & $\$ 964,406$ & 6,728 & 23,842 & 40,956 & 2,132 & 14,728 & 27,324 \\
\hline Booker T Washington & $\$ 18,023$ & 150 & 446 & 684 & -46 & 284 & 601 \\
\hline Cabrillo & $\$ 1,425$ & -3 & 35 & 74 & -8 & 16 & 39 \\
\hline Canyon de Chelly & $\$ 1,248,030$ & $-13,299$ & 30,854 & 75,007 & 2,245 & 33,073 & 63,901 \\
\hline Capulin Volcano & $\$ 13,067$ & 99 & 323 & 492 & 1,636 & 1,636 & 1,636 \\
\hline Casa Grande & $\$ 3,980$ & -40 & 98 & 236 & -81 & -11 & 58 \\
\hline Castillo de San Marcos & $\$ 0$ & 0 & 0 & 0 & 0 & 0 & 0 \\
\hline Castle Clinton & $\$ 0$ & 0 & 0 & 0 & 0 & 0 & 0 \\
\hline Cedar Breaks & $\$ 160,255$ & 1,667 & 3,962 & 6,257 & 592 & 2,601 & 4,610 \\
\hline Chiricahua & $\$ 143,424$ & $-2,426$ & 3,546 & 9,517 & $-1,535$ & 1,885 & 5,304 \\
\hline Colorado & $\$ 264,893$ & $-3,062$ & 6,549 & 16,160 & 551 & 7,272 & 13,993 \\
\hline Craters of the Moon & $\$ 524,499$ & $-5,762$ & 12,967 & 31,695 & $-6,639$ & 3,597 & 13,834 \\
\hline Devils Postpile & $\$ 22,641$ & 175 & 560 & 945 & 58 & 351 & 644 \\
\hline Devils Tower & $\$ 24,194$ & 184 & 598 & 911 & 1,892 & 1,892 & 1,892 \\
\hline Dinosaur & $\$ 2,462,532$ & $-27,738$ & 60,878 & 149,495 & 1,882 & 62,698 & 123,513 \\
\hline Effigy Mounds & $\$ 173,039$ & 2,833 & 4,278 & 4,736 & 37 & 4,173 & 6,664 \\
\hline El Malpais & $\$ 1,204,239$ & $-14,105$ & 29,771 & 73,647 & 5,774 & 37,662 & 69,551 \\
\hline El Morro & $\$ 8,286$ & -94 & 205 & 503 & -42 & 144 & 331 \\
\hline Florissant Fossil Beds & $\$ 106,185$ & 808 & 2,625 & 3,998 & 10,374 & 10,374 & 10,374 \\
\hline Fort Frederica & $\$ 20,805$ & 115 & 514 & 773 & 26 & 464 & 730 \\
\hline Fort Matanzas & $\$ 12,709$ & 67 & 314 & 474 & 11 & 278 & 440 \\
\hline Fort McHenry & $\$ 14$ & 0 & 0 & 1 & 0 & 0 & 0 \\
\hline Fort Pulaski & $\$ 291,072$ & 2,053 & 7,196 & 10,575 & 1,726 & 7,053 & 10,139 \\
\hline Fort Stanwix & $\$ 0$ & 0 & 0 & 0 & 0 & 0 & 0 \\
\hline Fort Sumter & $\$ 848$ & 2 & 21 & 33 & -4 & 13 & 23 \\
\hline Fort Union & $\$ 10,633$ & -7 & 263 & 532 & -11 & 140 & 292 \\
\hline Fossil Butte & $\$ 60,463$ & -666 & 1,495 & 3,656 & -552 & 709 & 1,970 \\
\hline George Washington Birthplace & $\$ 26,316$ & 208 & 651 & 958 & 91 & 541 & 849 \\
\hline George Washington Carver & $\$ 9,955$ & 66 & 246 & 352 & 19 & 165 & 228 \\
\hline Gila Cliff Dwellings & $\$ 13,373$ & 58 & 331 & 603 & 15 & 195 & 375 \\
\hline Grand Portage & $\$ 34,870$ & 420 & 862 & 1,101 & -305 & 693 & 1,290 \\
\hline Hagerman Fossil Beds & $\$ 25,749$ & -281 & 637 & 1,554 & -337 & 160 & 658 \\
\hline Hohokam Pima & $\$ 15,298$ & -152 & 378 & 909 & -309 & -43 & 224 \\
\hline Homestead & $\$ 2,867$ & 22 & 71 & 108 & 185 & 185 & 185 \\
\hline Hovenweep & $\$ 6,215$ & -70 & 154 & 377 & -44 & 91 & 226 \\
\hline Jewel Cave & $\$ 20,892$ & 159 & 516 & 787 & 1,767 & 1,767 & 1,767 \\
\hline John Day Fossil Beds & $\$ 212,236$ & -99 & 5,247 & 10,593 & -204 & 2,811 & 5,827 \\
\hline Lava Beds & $\$ 707,011$ & 1,686 & 17,479 & 33,271 & 191 & 9,927 & 19,664 \\
\hline Little Bighorn Battlefield & $\$ 13,607$ & 104 & 336 & 512 & 202 & 202 & 202 \\
\hline Montezuma Castle & $\$ 15,250$ & 19 & 377 & 735 & -11 & 200 & 411 \\
\hline Muir Woods & $\$ 17,369$ & 148 & 429 & 711 & -214 & 385 & 985 \\
\hline Natural Bridges & $\$ 53,766$ & -603 & 1,329 & 3,261 & -258 & 957 & 2,172 \\
\hline Navajo & $\$ 5,539$ & -58 & 137 & 332 & 0 & 133 & 266 \\
\hline Ocmulgee & $\$ 62,543$ & 584 & 1,546 & 2,248 & 244 & 1,315 & 2,031 \\
\hline Oregon Caves & $\$ 22,824$ & 243 & 564 & 885 & 86 & 371 & 656 \\
\hline Organ Pipe Cactus & $\$ 3,275,793$ & $-32,667$ & 80,984 & 194,634 & $-66,226$ & $-9,031$ & 48,165 \\
\hline Petroglyph & $\$ 105,913$ & -73 & 2,618 & 5,309 & -110 & 1,398 & 2,907 \\
\hline Pipe Spring & $\$ 309$ & -3 & 8 & 18 & -3 & 3 & 8 \\
\hline Pipestone & $\$ 4,318$ & 33 & 107 & 163 & 91 & 91 & 91 \\
\hline Poverty Point & $\$ 25,791$ & 172 & 638 & 942 & 121 & 615 & 904 \\
\hline Rainbow Bridge & $\$ 576$ & -6 & 14 & 35 & -7 & 4 & 15 \\
\hline Russell Cave & $\$ 28,826$ & 379 & 713 & 959 & 73 & 518 & 875 \\
\hline Salinas Pueblo Missions & $\$ 7,324$ & -82 & 181 & 444 & -64 & 90 & 244 \\
\hline Scotts Bluff & $\$ 53,383$ & 406 & 1,320 & 2,010 & 728 & 728 & 728 \\
\hline Statue Of Liberty & $\$ 521$ & 5 & 13 & 20 & -1 & 8 & 18 \\
\hline Sunset Crater Volcano & $\$ 49,175$ & 460 & 1,216 & 1,971 & 160 & 784 & 1,409 \\
\hline Timpanogos Cave & $\$ 8,116$ & 79 & 201 & 322 & 28 & 130 & 233 \\
\hline Tonto & $\$ 16,939$ & -10 & 419 & 847 & -17 & 223 & 464 \\
\hline Tuzigoot & $\$ 14,816$ & 29 & 366 & 704 & -10 & 193 & 396 \\
\hline Walnut Canyon & $\$ 158,158$ & 1,626 & 3,910 & 6,194 & 576 & 2,562 & 4,548 \\
\hline White Sands & $\$ 558,470$ & $-5,564$ & 13,806 & 33,177 & $-11,298$ & $-1,569$ & 8,160 \\
\hline Wupatki & $\$ 347,679$ & $-3,464$ & 8,595 & 20,654 & $-7,034$ & -868 & 5,298 \\
\hline Yucca House & $\$ 214$ & -2 & 5 & 13 & -3 & 1 & 5 \\
\hline National Park & $\$ 472,352,238$ & $2,920,372$ & $11,677,435$ & $19,631,114$ & $-176,223$ & $7,824,701$ & $14,816,269$ \\
\hline Acadia & $\$ 2,631,263$ & 43,227 & 65,050 & 72,864 & $-1,170$ & 60,551 & 99,873 \\
\hline Arches & $\$ 543,147$ & $-5,661$ & 13,428 & 32,517 & $-6,290$ & 4,338 & 14,966 \\
\hline Badlands & $\$ 1,828,144$ & 13,906 & 45,195 & 68,836 & 22,265 & 22,265 & 22,265 \\
\hline Big Bend & $\$ 8,057,402$ & $-83,252$ & 199,194 & 481,640 & $-158,917$ & $-10,810$ & 137,298 \\
\hline Biscayne & $\$ 584,390$ & 4,043 & 14,447 & 21,268 & 3,180 & 14,092 & 20,454 \\
\hline Black Canyon of the Gunnison & $\$ 1,187,580$ & 10,947 & 29,359 & 47,771 & 3,788 & 18,894 & 34,001 \\
\hline Bryce Canyon & $\$ 499,331$ & $-5,828$ & 12,344 & 30,517 & 2,296 & 15,469 & 28,642 \\
\hline Canyonlands & $\$ 2,130,932$ & $-21,493$ & 52,681 & 126,854 & $-19,239$ & 24,035 & 67,309 \\
\hline Capitol Reef & $\$ 1,512,969$ & $-16,976$ & 37,403 & 91,783 & $-9,059$ & 24,455 & 57,969 \\
\hline Carlsbad Caverns & $\$ 508,617$ & $-7,006$ & 12,574 & 32,154 & $-7,632$ & 3,019 & 13,669 \\
\hline Channel Islands & $\$ 3,079,051$ & $-5,445$ & 76,120 & 157,684 & $-14,946$ & 35,381 & 85,709 \\
\hline
\end{tabular}


Appendix 2 - NPS Unit Carbon Sequestration Estimates

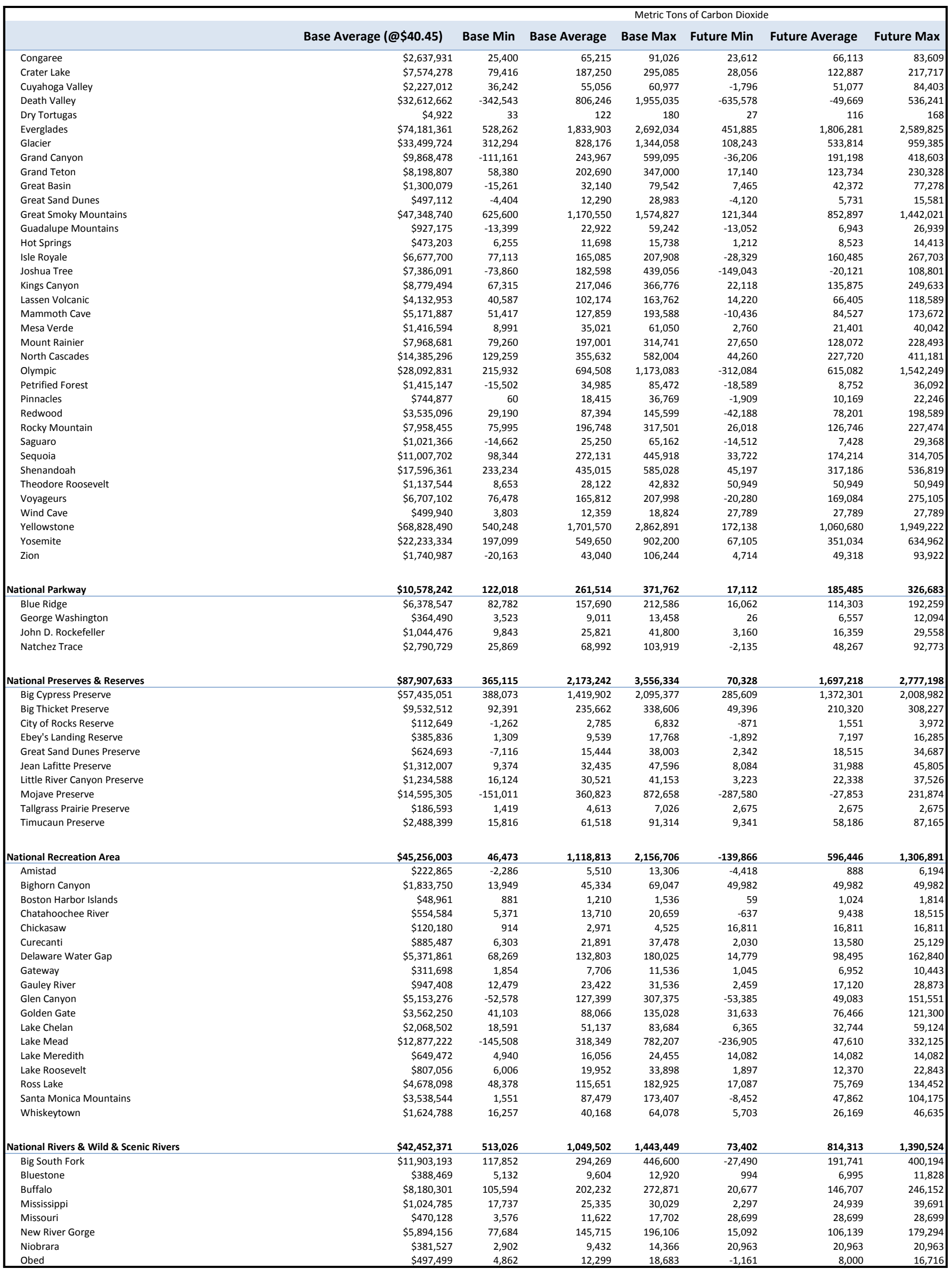


Appendix 2 - NPS Unit Carbon Sequestration Estimates

\begin{tabular}{|c|c|c|c|c|c|c|c|}
\hline & \multirow[b]{2}{*}{ Base Average (@\$40.45) } & \multicolumn{6}{|c|}{ Metric Tons of Carbon Dioxide } \\
\hline & & Base Min & Base Average & Base Max & Future Min & Future Average & Future Max \\
\hline Ozark & $\$ 7,130,734$ & 91,525 & 176,285 & 238,492 & 19,212 & 130,042 & 216,284 \\
\hline Saint Croix & $\$ 3,628,788$ & 42,851 & 89,710 & 113,246 & $-12,918$ & 85,048 & 139,337 \\
\hline Upper Delaware & $\$ 2,952,792$ & 43,311 & 72,999 & 82,434 & 7,036 & 65,040 & 91,365 \\
\hline Other Designation & $\$ 1,648,831$ & 16,412 & 40,762 & 61,687 & $-3,238$ & 27,022 & 55,359 \\
\hline Catoctin Mountain Park & $\$ 552,217$ & 5,508 & 13,652 & 20,704 & $-1,253$ & 8,916 & 18,570 \\
\hline Prince William Forest Park & $\$ 1,088,313$ & 10,821 & 26,905 & 40,678 & $-1,982$ & 17,957 & 36,510 \\
\hline Saint Croix Island International Historic Site & $\$ 255$ & 4 & 6 & 7 & 2 & 9 & 11 \\
\hline Wolf Trap Farm Park for the Performing Arts & $\$ 8,047$ & 78 & 199 & 299 & -5 & 140 & 268 \\
\hline Grand Total & $\$ 707,858,697$ & $4,239,685$ & $17,499,597$ & $29,160,754$ & $-206,979$ & $12,049,518$ & $22,312,678$ \\
\hline
\end{tabular}

